IRSH 5 I (2006), pp. I-40 DOI: I0.10I7/S0020859005002300

(C) 2006 Internationaal Instituut voor Sociale Geschiedenis

\title{
The Ballad of Bourg-Madame: Memory, Exile, and the Spanish Republican Refugees of the Retirada of $1939^{*}$
}

\author{
SHARIF GEMIE
}

Summary: This paper analyses the experience of the Spanish Republican refugees who left Catalonia in the Retirada of January and February 1939. The first section "the Road to Bourg-Madame" - considers issues of interpretation raised by the refugees' texts: it discusses historiography, the politics of memory, and political culture. In "Bourg-Madame", the second section, the essay considers the refugees' experiences. It discusses previous patterns of Spanish migration, the decisionmaking process that preceded the refugees' journey, group identity formation during the Retirada, the gendered dimension of their experiences, the despair felt by many on arrival in France and the reception that the refugees met. The paper ends by discussing the surprising resilience of the refugees.

"In itself", noted the I928 edition of the Guide Bleu for the Pyrenees, "Bourg-Madame offers nothing of interest". I This small settlement, with 507 inhabitants and one hotel, located at a height of I, I 46 metres, was the last village on the road which led from Perpignan to the French-Spanish border. Prospective visitors were advised to cross the border - a mere ten minutes walk - to the Spanish town of Puigcerdà, a more lively town, "full of local colour", with good hotels, a casino and attractive new buildings. Bourg-Madame was, of course, not the only settlement near the border. Along the line of the frontier, east of Bourg-Madame, were French villages such as Le Perthus, Prats de Mollo, Le Boulou, and, near the Mediterranean coast, Cerbère. ${ }^{2}$ An extraordinary flood of new visitors entered these little French Pyrenean settlements in the last days of January and the first days of February i 939. Hundreds of thousands of Spaniards,

* The author would like to thank Stefan Berger, Patricia Clark, Chris Ealham, Scott Soo, and Chris Williams for their useful comments on draft versions of this paper.

I. Marcel Monmarché, Pyrénées (Paris, I928), p. 465.

2. On the formation of this border, see the impressive work by Peter Sahlins, Boundaries: The Making of France and Spain in the Pyrenees (Berkeley, CA, 1989). Similar themes are also discussed in Peter McPhee, "Counter-Revolution in the Pyrenees: Spirituality, Class and Ethnicity in the Haut-Vallespir, 1793-94", French History, 7 (1993), pp. 313-343; and Sharif Gemie "France and the Val d'Aran: Politics and Nationhood on the Pyrenean Border, 1800-25", European History Quarterly, 28 (1998), pp. 3I I-346. 


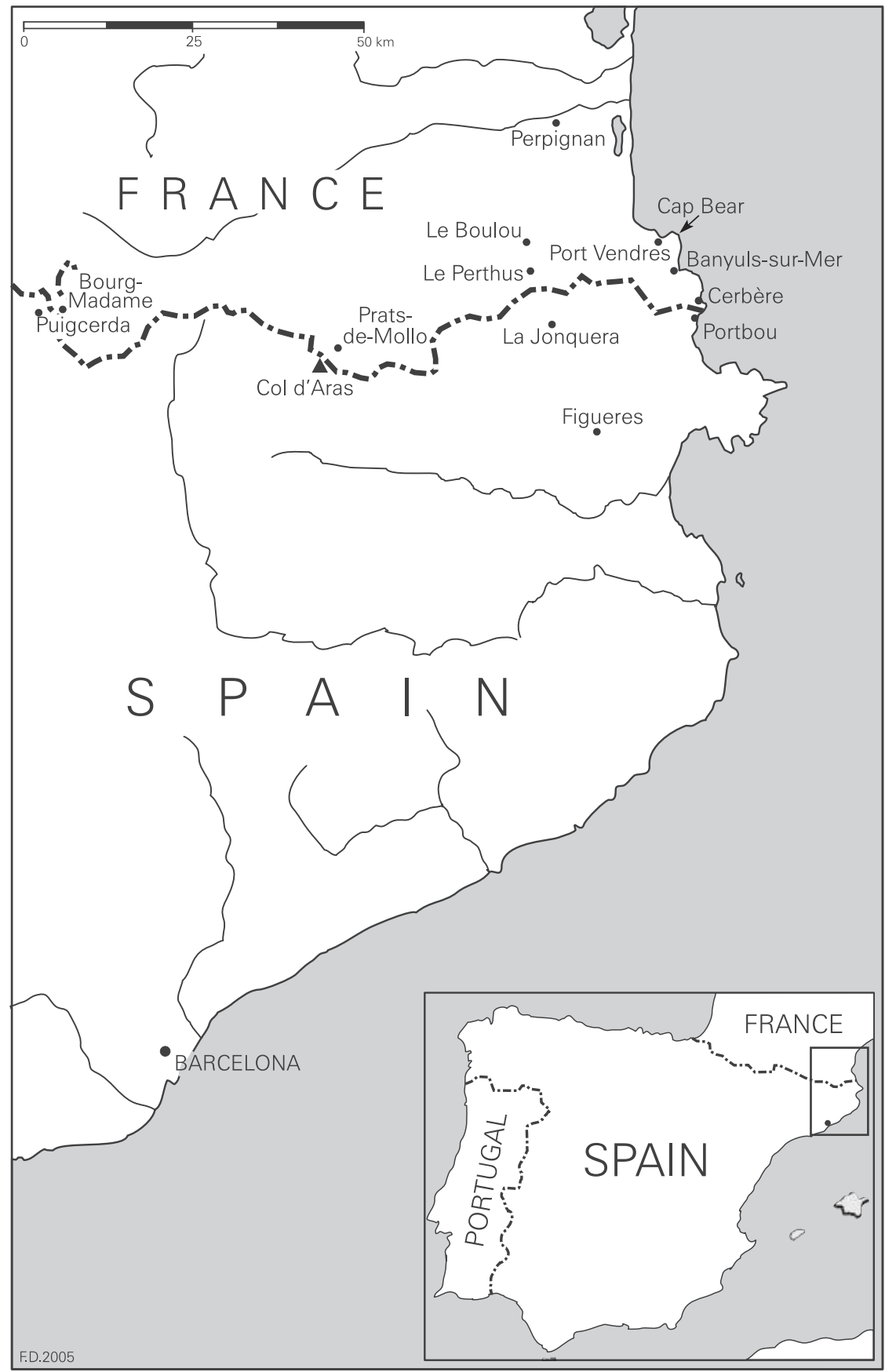

Figure I. Eastern border region between Spain and France. 
fleeing from the advancing Nationalist soldiers, collected in them after entering France: this movement of people was quickly termed the Retirada.

The "Ballad of Bourg-Madame" was written by these refugees (see Appendix, pp. 39-40). It was composed immediately after the border crossing, and then recorded in Paris in the summer of 1939. It is a simple song, teetering between proclamations of revenge, of maldición (curses) against the victorious nationalists, and a humbler, perhaps more honest, sense of desolation: "Tú, que abriste las puertas al fascismo tendrás eternamente nuestra maldición [An eternal curse on you who opened the doors to fascism]". ${ }^{3}$ This paper explores some of the themes suggested by the cancion and the experience of the refugees who crossed the Pyrenees in 1939. It examines in particular the factors which encouraged some provisional sense of group identity among them. We shall first consider some interpretative issues concerning historiography and the politics of memory, before turning to analyse the refugees' writing. ${ }^{4}$

\section{THE ROAD TO BOURG-MADAME}

\section{A traveller's history}

The collapse of the republican forces in Catalonia and the subsequent Retirada of refugees and defeated soldiers have featured in many studies. The event can be seen as one of the last chapters of the republican war effort, as an episode in the constitution of two opposing Spanish identities (republican and nationalist), as part of the growing international refugee crisis of the I930s, as an indication of the increasingly authoritarian trends in France prior to 1940 - the "Vichy before Vichy" - and as another step towards Franco's final seizure of power. 5 To date, however, no researcher

3. A version of this song can be found in the anthology of songs collected by Rolando Alarcón, Canciones de la resistencia y de la guerra civil española, vol. 2 (Discmedi 346 o2).

4. Note on spelling: when citing authors' names, I have followed the form of spelling used in their publications. Thus "Semprun" is listed as the author of the French-language Grand voyage, but his son, the author of El exilio fue una fiesta, is referred to as "Semprún".

5. Many useful studies have followed some of these lines of enquiry. Geneviève DreyfusArmand, L'exil des républicains espagnols en France; de la Guerre civile à la mort de Franco (Paris, 1999) is the most recent and most exhaustive study of the refugee experience. Alicia Alted Vigil, "La oposición republicana, I939-1977", in N. Townson (ed.), El Republicanismo en España (Madrid, I994) is a useful survey of the swirling political currents within the republican opposition. Anne Grynberg, Les camps de la honte: les internés juifs des camps français (1939-44) (Paris, I99I), considers the treatment of the Spaniards in French prisons before the establishment of a Jewish penal population. Gérard Noiriel, Réfugiés et Sans-Papiers: la République face an droit d'asile, XI-XXe siècle (Paris, 1998) is a stimulating and provocative analysis of French policies towards refugees; it includes a consideration of the Spanish experience. Paul Preston, Franco: A Biography (London, 1993) presents an authoritative account of Franco's rise to power and his subsequent dictatorship. 


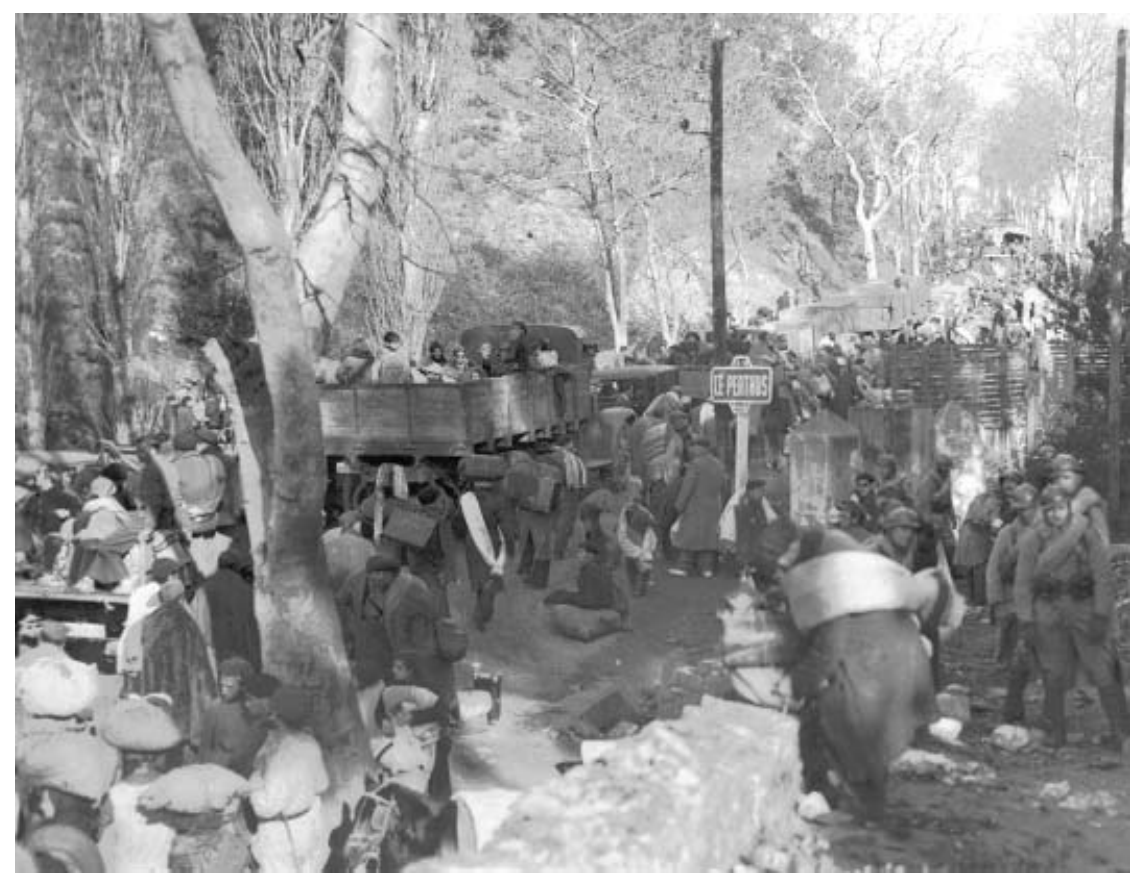

Figure 2. Early February 1939, a massive stream of tens of thousands of Spanish refugees from Figueras, heading for Perpignan, crossed the border near Le Perthus, after French authorities threw open border crossings.

IISH Collection, copyright Associated Press

has considered the refugees' experience in its simplest and most obvious form, in the form that they themselves experienced it: as a journey, a "contemporary Iliad", in the words of Dario Puccini. ${ }^{6}$ The pages which follow will focus specifically on the experience of the Retirada from Catalonia, with some wider comparisons drawn from other refugees' experiences.

Studying travellers can be difficult for historians. Certainly, some - such as Chateaubriand or Gautier - have left extensive, evocative records of their journeys. But, almost by definition, the traveller moves outside fixed territorial and conceptual borders: he or she may therefore be difficult to trace. Today, one of the concerns associated with the movement of refugees and asylum-seekers is that they are able to outwit the bureaucratic machinery of the state and merge, undetected and illegal, within the settled mass of the law-abiding population. A similar fear grew in France during

6. Dario Puccini, "Introduction" to Le romancero de la résistance espagnole, R. Paris (tr.) (Paris, 1962), p. I 2. While this essay provides a useful analysis of poetry, poets, and the conflict, Puccini does not develop his provocative idea of an Iliad. 
the I930s, initially provoked by the prospect of the mass entry of refugees from Germany, sometimes centred on the possibility that these migrants would compete with French workers for scarce jobs. ${ }^{7}$ Significantly, in the first months of 1939, the French state was unable to provide definitive estimates of the number of Spanish refugees who crossed the Pyrenees, because they had overwhelmed the state's capacity to measure immigration: estimates ranged from 353,107 to $514,337 .{ }^{8}$

These refugees' experience represented an extremely unusual form of travel, which should be distinguished from more common forms. Firstly, there are the daily journeys which we all make from, for example, from home to work which - while often suggesting important questions concerning the relationship of the individual to the environment - are rarely considered to be of historical importance. Secondly, there are journeys with symbolically important aspects. Moving from one house to another may only involve travelling a few streets within the same town, but such a journey can suggest important changes in status. The Retirada of I939, however, falls into a different category, which we could tentatively term a "journey of power": in other words, a journey by a mass of people which, in itself, forms a significant shift in wider power relations. As some refugees themselves noted, their experience was similar to that of the Jews expelled from the newly-Christianized sixteenthcentury Spanish state. 9 (Significantly, due to the anti-Arab sentiments of many Spanish republicans, none of them made the more accurate comparison with the experience of Arab and Berber Muslims expelled from Spain following the Reconquista. ${ }^{\mathrm{I}}$ ) In this third category, the journey is a transition from a situation of relatively secure status to a situation in which almost everything appears uncertain. In 1939, the refugees experienced a rapid, radical loss of power and status. To anticipate an element of the conclusion of our story, "we not only lost the war, we lost everything else too. Everything." II

\section{Memory in extreme situations}

Our analysis of the refugees' experience of the Retirada will largely be drawn from the refugees' own writing. Before analysing these texts, we

7. See, for example, Greg Burgess, "France and the German Refugee Crisis of 1933", French History, 16 (2002), pp. 203-229.

8. See Dreyfus-Armand, L'exil des républicains espagnols en France, pp. $35,53$.

9. See, for example, Federica Montseny, Pasión y muerte de los españoles en Francia (n.p., 1969 [1950]), p. 4 .

I०. On the long-term historical importance of this experience for Spanish political culture, see Juan Goytisolo, Cogitus Interruptus (Barcelona, I999).

I I. Neil MacMaster, Spanish Fighters: An Oral History of Civil War and Exile (London, 1990), p. 228. 


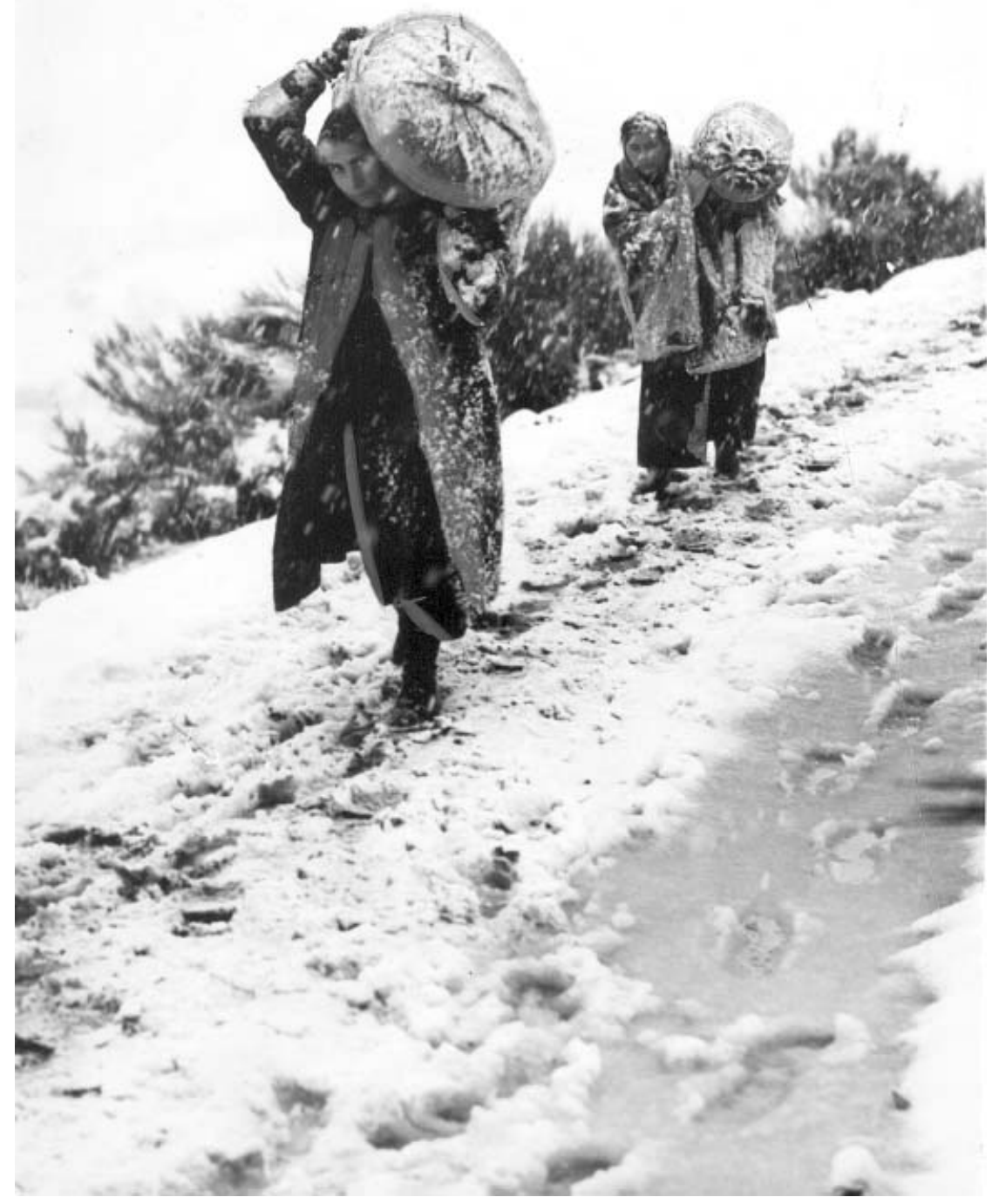

Figure 3. Refugee women in the snow on the Col d'Aras, early January 1939. IISH Collection, copyright Agence Trampus

need to identify them more precisely, and consider their qualities as sources of information. In the sections which follow, I will initially adopt a simple definition of what constitutes "refugee writing": any text written by an anti-Francoist refugee which reflects on the refugee experience and/or 
on events in Spain. ${ }^{\mathrm{I} 2}$ As will be seen, some recent works have suggested challenges to this simple definition.

It is obvious that the Spanish republicans were not a unified grouping. In part, however, this easy recognition of the republicans' factionalized disunity is a result of a historically-based "visual illusion", whereby it is easy to "see" the winning side as the most united, and to perceive Franco, El Caudillo, as successfully imposing a type of heroic, charismatic moral unity on his disparate forces. The comparison between the two opposing forces is, in reality, more complex than these simplistic clichés suggest. It is worth noting that there were long-term political and cultural tensions within the Francoist camp: between modernizers and traditionalists, Falangist militants and conservative notables, Germanophiles, Italophiles, Atlanticists and Spanish patriots, republicans and monarchists, secularists and Catholics. ${ }^{13}$ In other words, the key difference between the two sides was not that one was united and the other chaotic. Both were ramshackle coalitions, with obvious internal tensions. Thus, while phrases such as "Francoists" and "anti-Francoists" are certainly convenient shorthand terms by which to identify the protagonists, they are not sufficiently precise for a full analysis: certainly, the term "anti-Francoist" does little to explain the consistency of the refugees' opposition.

The conflict that erupted in 1936 was less clear-cut than the neat black lines on military maps suggest, and it is no coincidence that no adequate term has been devised as a label to describe it. The most common phrase "the Spanish Civil War" - can be criticized on several counts. Firstly, that the military conflict was ultimately decided by foreign intervention: by January I 937, due to German, Italian, and Russian military intervention, it had effectively ceased to be simply "Spanish". Secondly, for many participants, on both right and left, the conflict was part of a longer cycle of revolution and counter-revolution: the phrase "civil war" downplays and sidelines these significant socio-political issues. For these reasons, the more appropriate term "the conflict" will be used throughout this paper.

These points suggest that there was no clear, simple political quality which united the refugees and so provided an element of consistency to their writing. We will now turn to consider the refugees' writing in relation to recent debates concerning the structuring of memory.

It has become a truism that contemporary society is obsessed with commemorations. It was from this first observation that Pierre Nora devised the project that grew into his astonishingly original multi-volume collection, Les Lieux de Mémoire, and the point has since been accepted as

12. Michael Ugarte, Shifting Ground: Spanish Civil War Exile Literature (Durham, 1989) presents some relevant considerations of this refugee culture. Unfortunately, however, Ugarte adopts a quite conservative, restrictive definition of "literature", which rules out much of the flood of pamphlets, autobiographies, and polemics produced by the refugees.

I3. Further discussions of these tensions can be found in Preston, Franco. 
a telling indication of the psychological or cultural decadence of advanced industrial societies, cut off from the authentic and spontaneous memory forms of their ancestors. ${ }^{\mathrm{I}} 4$ The argument, however, remains open to question. Nora's studies concerned what he considered as the fading remnants of the older, more authentic forms of memory: his lieux tend to be zones of mediation between governmental authority structures and popular cults, and his authors usually study the processes of negotiation around each site. There are few examples in his collection of genuinely nongovernmental forms of commemoration, and even here - for example, in Philippe Joutard's study of the Protestant minority culture in France there existed strong social institutions to structure and direct memory. ${ }^{\text {Is }}$ This type of model is clearly inapplicable to memory culture of the Spanish refugees. Their memories of the conflict were marginalized; particularly in the crucial months following the Retirada there were no institutions to structure them.

We can learn more about the nature of the refugees' memory culture from an older work, Bruno Bettelheim's The Informed Heart. At approximately the same time that the refugees of the Retirada were being herded into concentration camps or dispersed into French villages, Bettelheim was imprisoned in the German concentration camps of, firstly, Dachau and then Buchenwald. A trained psychologist, his study of concentration camp life is an exceptional document of survival "in an extreme situation" ${ }^{16}$ In citing his memoir, I have no intention to relativize the Jewish experience of the Holocaust. It is clear that the German Jews were hit by a unique killing machine whose punitive ferocity was unlike anything else the world has ever known. Comparisons between the two groups, however, were made during the I930s and I940s. Both entered the dreadful shadows of "l'univers concentrationnaire", even if the quarters inhabited by the Spanish refugees were less bloody than those in which the Jews were placed.

Bettelheim warns of the dynamic of Nazism: the concentration camp was a machine to produce the disintegration of the individual, reducing its inhabitants to "a docile mass". ${ }^{17}$ Bettelheim's agonizing account of the bleak dilemma that he faced includes reflections on the nature of identity and memory. He notes how the inmates began to view the prospect of a return home with a strange ambivalence, for their aim was "to return home

I4. For variants on this theme, see Adrian Forty, "Introduction" to A. Forty and S. Küchner (eds), The Art of Forgetting (Oxford, 1999), pp. I- I 8; Peter France and Siân Reynolds, "A PostModern Cathedral?", Modern and Contemporary France, 4 (1996), pp. 227-23 I; Nancy Wood, Vectors of Memory: Legacies of Trauma in Postwar Europe (Oxford, I999), p. I.

I 5. Philippe Joutard, "Le musée du désert: la minorité réformée”, in P. Nora (ed.), Les Lieux de Mémoire, vol. 2 (Paris, 1997), pp. 2653-2677.

16. Bruno Bettelheim, The Informed Heart: The Human Condition in Mass Society (London, 1970), p. 23.

17. Ibid., p. 103. 
exactly the same person who had left", and they began to realize that the camps were changing their identities in a profound, and possibly permanent, manner. ${ }^{18}$ The restructuring of their memories was part of this process. Bettelheim's solution was to use his skills as a psychologist to study and therefore understand, even to transcend, his situation. But part of any study is the recording of experience, and in the camps this was extremely difficult. Bettelheim had no access to writing material, and so had to memorize relevant data. The conditions of the camps made even this process difficult: the inmates' days were structured around seventeen-hour labour shifts, involving "senseless tasks", and rapid, arbitrary changes in camp policy. ${ }^{19}$ The inmates lost that autonomy which is normally needed for the construction of memory: under these circumstances, "one remembered facts which one had been told to learn, not those which one wished to acquire for oneself". ${ }^{20}$ Without exaggeration, one could describe Bettelheim's successful writing-up of his experiences as an act of antifascist resistance.

But why was it necessary to remember such experiences? Another camp inmate, the Spanish Republican Jorge Semprun, considered that when he left Buchenwald he had two choices: writing or living. For him, living meant being silent about what could not be expressed. ${ }^{21} \mathrm{He}$ observed this rule for some fifteen years, until he was ultimately driven to write his $L e$ Grand Voyage in 1962. His final turn to writing was a painful step, but clearly a necessary one. Like so many other republican refugees, he was motivated by a need to affirm his memory. Like Semprun, many republican refugees felt a need to structure and record their memories of the Retirada. Like Bettelheim, they often attempted this work in adverse circumstances. What motivated them to take this step?

There are many reasons for this powerful and common desire to record a painful experience. Such acts clearly aim to produce a form of commemoration: as Michael Roberts perceptively observes, the aim of a memorial is to produce a reconciliation of a grieving individual and a milieu. One of the most common ways of doing this is by making death and suffering into meaningful social experiences, usually by interpreting them as heroic self-sacrifices for some higher cause. ${ }^{22}$ There are still very few public memorials to mark the experiences of the Spanish exiles: these refugee texts are informal, private, imperfect substitutes for the more formal, public and prestigious rituals analysed in Nora's collection. This point can also suggest a criticism of Nora's work: perhaps the reason why

I8. Ibid., p. I76.

19. Ibid., p. I38.

20. Ibid., p. I80.

21. Jorge Semprun, L'Ecriture ou la vie (Paris, 1994), p. 235.

22. Michael Roberts, "Remembering to Forget: Sublimation as Sacrifice in War Memorials", in Forty and Küchner, The Art of Forgetting, pp. I 29-145. 


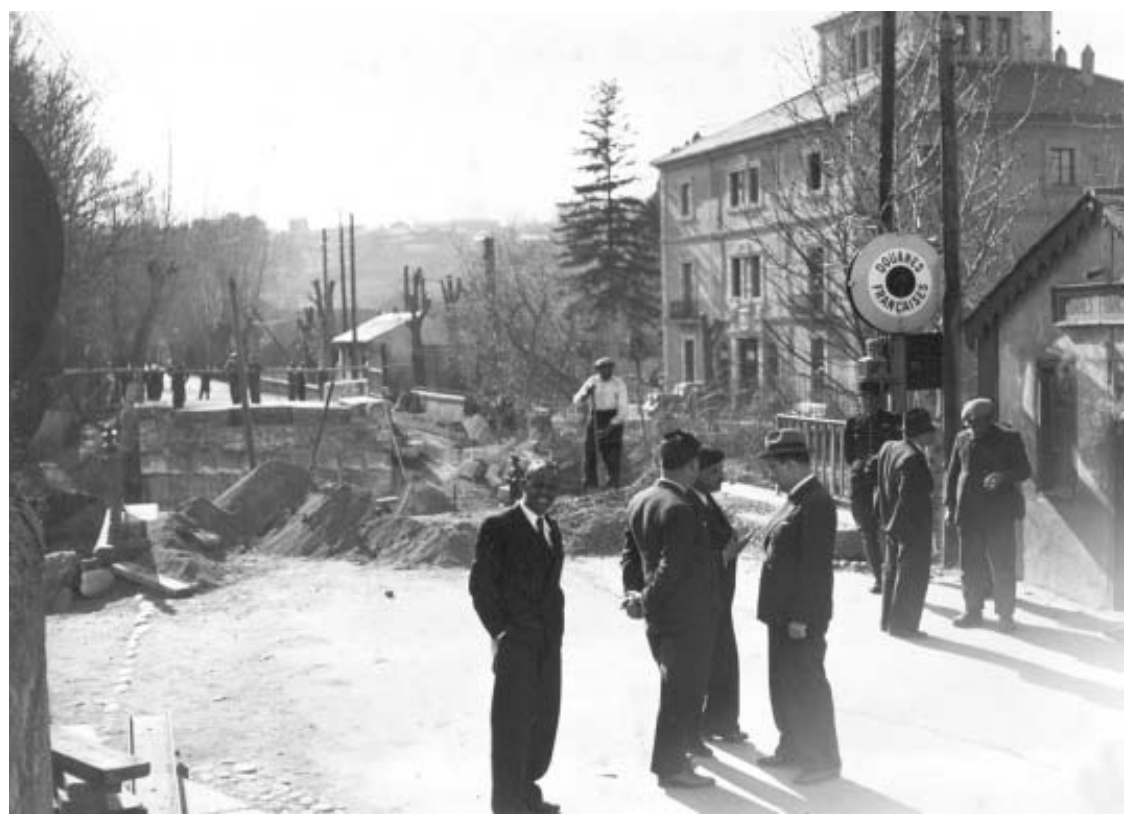

Figure 4. Broken-up road at border crossing in Bourg-Madame, 1939. Refugees were forced to cross the French-Spanish border through a ford in the nearby river.

IISH Collection, copyright Wide World Photos

the urge to commemorate became so powerful in the twentieth century was because the peoples of the twentieth century had suffered greater trauma than previous generations, rather than because of any qualitative decay in their forms of memory.

Alongside this quest for reconciliation of individuals with their milieu, other causes clearly motivated the exiles to write. In part, their texts are blatantly and aggressively political, an aspect of a long anti-Francoist struggle. While Spain's new authorities sought to fix a single, orthodox memory of the conflict, the refugees refused to allow their experiences to be ignored and marginalized. Like Bettelheim's studies, their texts were a form of revenge against the Francoist authorities. ${ }^{23}$ John Beverly's subtle concept of testimonio captures something of the ideal of this project. These writers were not motivated by a desire to present themselves as individual heroes: instead they wished to illuminate the "problematic collective social situation" through which they had lived. ${ }^{24}$ The ideal goal of this politicized writing was to produce collective solidarity among the refugees, not

23. As noted by Laborie and Almaric, "Mémoires en devenir", p. is.

24. John Beverly, "The Margin at the Centre", in S. Smith and J. Watson (eds), Decolonizing the Subject (Minneapolis, MI, I992), pp. 9I-I I4, 95. 
individual glory. On the other hand, elements were also present in their works which prevented the easy construction of reconciliation and solidarity. Within their works, there are also partisan assertions, settlings of scores, and aggressive, polemical dismissal of rival groups.

How should we analyse these refugees' works? They are, by any historical measure, unusual texts: in particular, their analysis goes "against the grain" of the forms of historiography which have dominated studies of mid-twentieth-century Spain. Here, historical writing concerning the conflict of 1936-1939 is dominated by institutional-political histories, whether of governments, parties or - sometimes - trade unions. Such works often assume "an essential unity" within the parties and organizations, and ignore the point made by Alberto Melucci: all movements are products of "multiple and heterogeneous social processes". ${ }^{25}$

Obviously, political-institutional history does serve certain useful functions: it would be absurd to argue, in some dogmatic fashion, that it was inherently "wrong". The point which I want to stress here is that the methods of political-institutional historiography are clearly inappropriate to the study of Spanish refugees' experience. Quite simply, there are no relevant party or governmental archives, no mass organizations and no prestigious leaders that can be taken as representing these refugees. Worse still, these people are caught between two nations - Spain and France and even, arguably, coming into the orbit of a third, Germany. To study such people, we need to use a different historical method, inspired by cultural history and anthropology, and more sensitive to the experience of ordinary individuals in extraordinary and extreme situations. It was essentially emotional qualities, I will argue, that drew the refugees together, and that prevented them dissolving into what Bettelheim termed "a docile mass". In proposing to write this form of history, I am inspired by Melucci's dictum that "there is no cognition without feeling and no meaning without emotion". ${ }^{26}$

The extent to which these works are genuinely representative of the mass experience of the hundreds of thousands who joined the Retirada is an awkward question to answer, for it is difficult to devise some form of empirical counter-experiment by which to check them. On occasion, there are inconsistencies in their narratives: these are noted in the pages that follow. There are also some frequent assertions of partisan political loyalty: however, these are rarely directly relevant to history of the Retirada. It seems probable that when specifically considering this episode, Beverly's concept of testimonio makes sense. Lastly, even where we have reason to suspect the honesty, the accuracy, or the typicality of a

25. Alberto Melucci, Challenging Codes: Collective Action in the Information Age (Cambridge, I996), p. 20.

26. Ibid., p. 7I. 
particular text, it remains true that it is these works that constitute the stilluncommemorated "memory" of the Retirada, an invisible lieu de mémoire.

The course of Spanish history has made it more difficult to resolve these fundamental interpretative problems. In the years after 1939 the Francoist authorities strove to create a hegemonic control over the memory of the conflict, integrating it into their wider vision of "an authentic and eternal Spain", stretching back to the first Catholic monarchies after the Reconquista. ${ }^{27}$ These historiographical deficiencies were then exacerbated by the form in which post-Francoist governments developed. Their dominant tendency was to avoid the awkward and painful issues created by the conflict, and to recommend a reconciliation of the victors and the defeated through a process of forgetting. This strategy certainly avoided another social conflict breaking out in the late I970s, but it left unaddressed many important issues concerning the republicans' experiences. ${ }^{28}$ In different ways, the Francoist state of 1939 and the constitutional monarchy of 1977 both silenced the maldición that echoed from Bourg-Madame.

Such considerations may initially sound almost irrelevant to the experience of the refugees of the Retirada. In practice, however, these apparently quite abstract issues had a direct bearing on personal identityformation within the exile community.

\section{Writing in exile}

There was a central paradox within the exiles' writing. The quality which most brought them together - their experience of the conflict - was also that which most divided them.

The half million or so refugees who crossed the Pyrenees early in 1939 were not members of a single party. While the majority were Catalan, among them there were also internal refugees from other Spanish regions, and conscripted soldiers in the republican army. They included many political activists who had participated in the socio-political projects of the conflict, such as the anarchist-inspired collectives and militia of 1936, the political institutions of Catalan autonomy, and the communist-directed drive to create a professional, disciplined army. Their defeat and expulsion

27. David K. Herzberger, Narrating the Past: Fiction and Historiography in Postwar Spain (Durham, I995), p. 21. See also Alberto Reig Tapia, "Historia y memoria de la guerra civil española”, in M. Papy (ed.), Les Espagnols et la guerre civile (Biarritz, I999), pp. 4I I-437.

28. Santos Juliá, "De 'guerra contra el invasor' a 'guerra fraticida”, in his edited collection of essays, Víctimas de la guerra civil (Madrid, I999), pp. I I-55, is an important and long-needed contribution to this debate. See also Paloma Aguilar, "Justice, Politics and Memory in the Spanish Transition”, in A. Barahona de Brito, C. González-Enríquez, and P. Aguilar (eds), The Politics of Memory (Oxford, 200I), pp. 92-I I8. 
did not encourage a sense of unity among them. The quest to understand their experience and - more brutally - to blame someone for their defeat, led to an increased awareness of the qualities which divided them. Moreover, it should never be forgotten that their political ideals did not die with the crossing of the border, but continued to inspire them and to guide them to create new political projects. All these exiles had to define their relationship with the spasmodic attempts by the internal Spanish anti-Francoist groups to organize resistance movements; Spanish Communist Party militants confronted the implications of the Nazi-Soviet Pact of August 1939; anarchist and anarcho-syndicalists considered their relationship with the various republican governments-in-exile; while the centrist republican groups debated projects to gather together the various tendencies among the refugees.

Further divisions were also created among the refugees by their place of settlement. Those who left in the Retirada and settled in France were unusual in that they included a real cross-section of Catalan society: while exact figures are difficult to establish, there can be no doubt that many were working-class and that probably the anarcho-syndicalist CNT was their majority tendency. ${ }^{29}$ Other waves of refugees were located elsewhere. Many Basque children were evacuated from Spain in 1937, and had already been relocated in small groups across Europe and the USA before 1939. Many republican and communist officials left in March I939, principally from the eastern Spanish port of Valencia. Most of them initially stayed in Algeria and elsewhere in the French Magreb..$^{\circ}$ Of their number, about 3,000 key PCE (Spanish Communist Party) militants then crossed France and left from Le Havre to Petrograd in May 1939. Other republican officials and intellectuals often managed to leave for Mexico. The PSOE (Spanish Socialist Workers' Party) leadership was literally split: those who had come to follow communist direction during the conflict often left for the USSR, those who refused it usually travelled to Mexico. ${ }^{3}$ Lastly, some trained professionals sought positions in the USA. ${ }^{32}$

Table I overleaf gives some estimate of the eventual geographic location of the refugees. It is incomplete: no data is given for the Soviet Union or for the countries of Latin America. It also fails to include the number who returned to Francoist Spain. While one cannot simply "read off" a political tendency from a refugee's geographic position, political factors were important in placing them.

29. This point is discussed at length in Dreyfus-Armand, L'exil des républicains espagnols en France, p. 192, and passim.

30. On the experience of refugees in Tunisia, see Amire Aleya Sghaier, "Les réfugiés espagnols républicains en Tunisie en 1939”, Mowvement social, i8 I (I998), pp. 3 I-52.

3I. On the political experience of the PSOE, see the useful case study by José Martínez Cobo, "Le PSOE à Toulouse et dans le Midi de la France", in L. Domergue (ed.), L'exil républicain à Toulouse (Toulouse, 1999), pp. 79-96.

32. See Dreyfus-Armand, L'exil des républicains espagnols en France, pp. 190-191. 
Table I. Estimates of numbers of Spanish republican refugees in $1945 .{ }^{33}$

\begin{tabular}{lr}
\hline Host country & Number of refugees \\
\hline France & $125,000-180,000$ \\
Algeria & 17,000 \\
Morocco & 1,000 \\
Tunisia & 900 \\
Belgium & $1,000-2,000$ \\
Mexico & 28,000 \\
\hline
\end{tabular}

Those of the Retirada who stayed in France after I 940 can be defined as a type of rank and file, left largely without republican or communist leadership. The refugees' experience placed severe constraints on the process of identity-formation. These exiles did not have the freedom to discuss and exchange interpretations. Their immediate post-Retirada experience was one of continual division, disruption, and fragmentation. Directly after crossing the border, adult males were separated from women and children. Men were usually dispersed into concentration camps, women and children were scattered in small groups across France. ${ }^{34}$ PreVichy censorship and a growing French sense of xenophobia denied them meaningful access to public dialogue. There are therefore very few works published by Spanish refugees in this period, and the death of the seventyfour-year-old republican poet, Antonio Machado, at the French border town of Collioure on 22 February 1939 can be seen as an emblematic event, symbolizing the silencing of the refugees' voices. (Later, Machado's grave would become a rallying-point where internal dissidents from Spain would meet exiled writers and poets. ${ }^{35}$ ) The most significant publications reflecting their experience are a handful of articles in sympathetic French left-wing papers and in the few editions of Spanish left-wing papers that were briefly published in France.

Following the French defeat of June 1940, and the German occupation of the north and west of the country, conditions grew worse. Refugees were overwhelmed by the shifts in authority relations; conditions of censorship grew stricter; and about 7,000 Spanish republican refugees were eventually sent to the concentration camp of Mauthausen. ${ }^{36}$ For many, the period of occupation was one in which they experienced a real terror. These divided, dispersed refugee groups were unable to express any united

33. Figures from Jacques Vernant, The Refugee in the Post-War World (London, 1953), p. 59. 34. Anne Grynberg estimates that approximately 226,000 Spanish refugee men were placed in five hastily constructed camps in March 1939. See her Les camps de la bonte, p. 4I.

35. Puccini, "Introduction", p. 43.

36. The experience of Spanish concentration camp victims is discussed in Emile Temime, "Les Espagnols à Mauthausen”, in Papy, Les Espagnols et la guerre civile, pp. 361-378. 


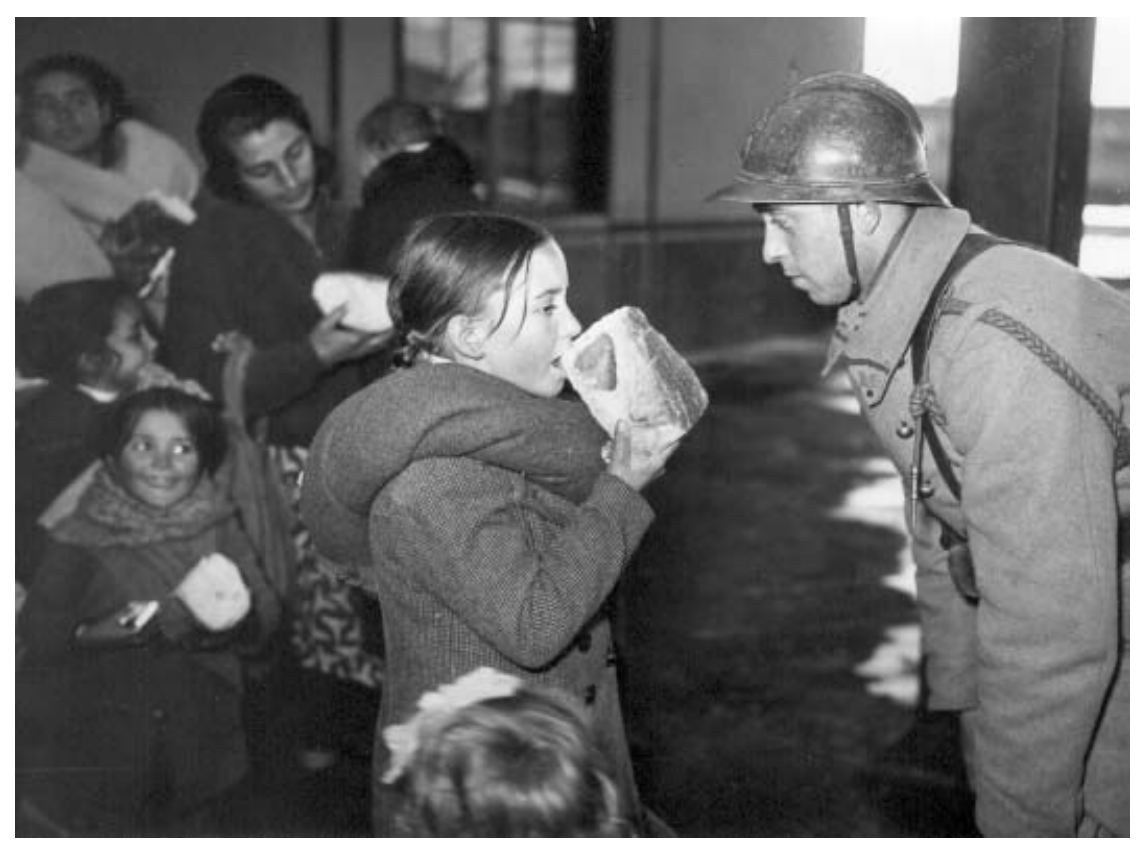

Figure 5. In Bourg-Madame French soldiers distribute bread among Spanish women and children refugees before they are transferred to refugee camps (February 1939).

IISH Collection, copyright Keystone

response to these changes, although many small groups were active as "passeurs" over the Pyrenees, or in guerrilla activities connected with the French Resistance. ${ }^{37}$ Once again, few refugees were able to publish their thoughts during this period: one of the rare exceptions is José Antonio de Aguirre's Escape via Berlin. This work, by the ex-President of the Basque region, was, significantly, first published in the USA and was intended to contribute to the American war effort, with the long-term aim of drawing the American government into a more actively anti-Francoist position. ${ }^{3}$

In 1944-I945 there was an "explosion of joy" among the refugees. ${ }^{39}$ In Toulouse, the (Francoist) Spanish Embassy was even briefly occupied by Spanish exile groups. French public opinion now showed some real sympathy for their plight. It was during this period that Albert Camus 37. On the activities of the "passeurs", see Emilienne Eychenne, Pyrénées de la liberté: les évasions par l'Espagne, 1939-45 (Toulouse, 1998). On refugee activities in the French Resistance, see the useful case study by Jean Ortiz, "La Résistance espagnole en Béarn", in Papy, Les Espagnols et la guerre civile, pp. 379-410.

38. José Antonio de Aguirre, Escape via Berlin: Eluding Franco in Hitler's Europe, Robert P. Clark (ed.) (Reno, NE [etc.], i99i [1944]).

39. L. Domergue, "La presse espagnole de l'exil à Toulouse et dans le midi de la France", in idem, L'exil républicain à Toulouse, pp. 207-224, 207. 
published several short texts concerning the conflict, its legacy, and the refugees. He considered that their struggle had been the "first battle" in the war against fascism..$^{\circ}$ To many, it appeared obvious that the next step by the victorious allies would be to defeat Francoist Spain, Europe's last fascist power. Correspondingly, Francoist ideologues began to remake the regime's image, denying its previous connections with Nazi power, and stressing its contribution to international anti-communism. Organized political groups re-emerged among the refugees, and a messy, noisy, and sometimes even violent debate took place concerning the place of the Communist Party. ${ }^{4 \mathrm{I}}$

Some refugees began to publish works concerning their experience. Typical of this period were works like Montseny's Pasión y muerte or Palencia's Smouldering Freedom. ${ }^{22}$ Both were figures with significant political connections: Montseny was a leading anarchist speaker and an exgovernment minister; Palencia is less well-known, but - through her husband - was linked to the Mexico-based government-in-exile. Such works are marked by both an urgency and an optimism: their authors consider that the political case presented by the republican exiles is unanswerable, and that soon European governments would act to aid the return of a republican government to Spain.

These hopes were to be dashed. With the onset of the Cold War, western governments moved to a grudging toleration of the Francoist regime, economically and militarily too valuable to attack. ${ }^{43}$ Politically, the exile groups remained irreconcilably split, although they were often united by their loyalty to a common cultural inheritance. ${ }^{44}$ The chances of a rapid restitution of the Spanish republic began to fade. In the r950s, correspondingly, there was a sharp decline in the number of refugee publications. For many, for example, Juan Goytisolo and Jorge Semprun, this was a tense period, marked by shifts in their awkward relationship

40. Albert Camus, "Préface à L'Espagne Libre", in Essais (Paris, I965), pp. 1604-1608, 1604. 4I. On the fate of the PCE in exile, see the useful case study, V. Marcos Alvarez, "Les communistes espagnols dans l'exil en région toulousain”, in Domergue, L'exil républicain à Toulouse, pp. I $2 \mathrm{I}-40$.

42. Isabel de Palencia, Smouldering Freedom: The Story of the Spanish Republicans in Exile (London, 1946).

43. For a useful analysis of British policy during this period, see David J. Dunthorn, "The Prieto-Gil Robles Meeting of October 1947: Britain and the Failure of the Spanish Anti-Franco Coalition, 1945-50", European History Quarterly, 30 (2000), pp. 49-75. French government reactions are discussed in Anne Dulphy, "Peut-on parler d'une génération de Français de la guerre civile?", in (no ed.), Enfants de la guerre civile (Paris, I999), pp. I5-30. A broader, international perspective is given in Enrique Moradiellos, "The Potsdam Conference and the Spanish Problem”, Contemporary European History, Io (200I), pp. 73-90.

44. On the importance of culture for the exile communities, see V. Izquierdo, "Art et exil: cinq artistes plasticiens espagnols en exil à Toulouse”, in Domergue, L'exil républicain à Toulouse, pp. $225-242$. 
with the Spanish Communist Party. At first the party acted to sustain their hopes that Spain would very shortly be liberated. Slowly and unwillingly, Goytisolo came to realize that "the regime would last as long as the hateful figure of its creator". 45

In the late I960s and early I970s, however, it became clearer that Franco's days were numbered. The end of the regime would not be produced by the type of mass action for which the exiles had hoped: but it would arrive. Refugee writing during this period is very varied. One can cite the intense, sophisticated, modernist narrative by Semprun, Le Grand Voyage, or the simple, angry prison memoirs of Miguel Garcia, Franco's Prisoner, as indications of the breadth of forms of writing produced in this period. $4^{6}$

Franco's death in 1975 stimulated a new wave of memoirs, often written with one eye on political developments in the new Spain. Censorship was now over, and there was, in principle, a new audience for exiles' memoirs in Spain itself. The reception of these exiles, however, returning after thirty-six years, was a difficult and often unhappy process. If they insisted on their special status as representatives of the "true" Spain, then this usually implied underestimating the importance of autonomous, internal political developments within Spain. On the other hand, accepting that a chapter had ended without their participation was equivalent to denying their own specific political legitimacy. The memoirs of "El Campesino" (1978), telling of his political journey from anarcho-syndicalism, through communism, to support for the candidates of the PSOE in the 1977 general elections can be cited as typical of this moment. ${ }^{47}$

When it became clear that, in reality, the old exiles were not going to be given a prominent status in the governments of the new constitutional monarchy, this wave of politically-orientated writing declined. In the I980s, however, a new cycle began. In these cases, the authors had no immediate political aim: no expectation of governmental positions or republican restoration and - for many - no real desire to return to a Spain which was no longer familiar to them. Often, their first language was now French. They remained, however, extremely emotionally committed to their experience..$^{8}$ Some were also often consciously influenced by

45. Juan Goytisolo, Realms of Strife: Memoirs, 1957-82, P. Bush (tr.) (San Francisco, CA, 1990), p. 5 I.

46. Jorge Semprun, Le grand voyage (Paris, 1963), and Miguel Garcia, Franco's Prisoner (London, 1972).

47. "El Campesino", Jusqu'à la mort (Paris, 1978).

48. In this sense, there is a comparison to be made with debates within Jewish writing concerning the Holocaust. The Spanish refugee writers show no sense of forgiveness. See ch. 3 of Nancy Wood, Vectors of Memory: Legacies of Trauma in Postwar Europe (Oxford, 1999). On the preservation of a Spanish republican identity in contemporary France, see Scott Soo's imaginative essay, "Diasporic Memories, Counter-Memories And Inter-Ethnic Memories: les lieux de mémoire and Spanish Civil War refugees in Southwest France", in Henrice Altink and 
historiographical considerations: they speak explicitly about the politics of memory and identity and - in some cases - their works were the result of collaboration with professional historians. ${ }^{49}$ In other cases, their works were edited by their children. ${ }^{50}$ At the very limits of autobiographical memory is a work like Antoine Blanca's Itinéraires d'un républicaine espagnol. ${ }^{\mathrm{I}}$ In this novel, the son of a republican exile has attempted to recreate his deceased father's experience by consulting his father's diary and reconsidering the stories his father had told him.

This last wave of writing is undoubtedly the most interesting. To some extent, it moves away from the factional squabbles that marked previous works, and often suggests a profound critique of the constraints and style of historiography which has been dominant in Spain since 1936 - if not even earlier. While rarely explicitly committed to causes such as women's history, a genuinely libertarian sense of an anti-hierarchical methodology often inspires these works. Ana Delso's Trescientes hombres y yo [Three Hundred Men and Me] can be cited as typical of this new wave. ${ }^{52}$ Even the title problematizes her status, as the only woman in a work camp in occupied France.

Since 1939 the experiences of the refugees of the Retirada had been ignored by the Spanish state. It is only in recent years that there have been some signs of a significant change in attitude. One small indication of this shift was the special issue of the El País colour supplement on I 2 January 2003 , which was devoted almost entirely to the experience of republican refugees across the world. 53 To this can be added the success of two recent novels: Manuel Rivas's El Lápiz del Carpintero and Javier Cercas's Soldados de Salamina, both of which discuss the fate of the defeated after the Francoists' victory. ${ }^{44}$ Alongside these debates are number of local

Sharif Gemie (eds), At the Border: Margins and Peripheries in Modern France (Cardiff, forthcoming).

49. In this respect, Ronald Fraser's oral history, The Blood of Spain (Harmondsworth, I98 I) could be seen as creating a new paradigm. MacMaster's Spanish Fighters is a collaboration between a professional historian and his exiled parents-in-law. Antonio Soriano, Éxodus: historia oral del exilio republicano en Francia, I939-1945 (Barcelona, 1989) is another oral history project, but suffers from the restricted range of interviewees used by Soriano.

50. For example, Dolores Torres, Chronique d'une femme rebelle (Paris, 1997).

51. Antoine Blanca, Itinéraires d'un républicaine espagnol (n.p., 2002).

52. Ana Delso, Trescientes hombres y yo (Madrid, I998). This work is a translation from a French-language original.

53. Alongside some moving and imaginative texts and photos there was, however, the incongruous retention of El Pais's regular fashion section. The reader is thus shunted from pictures of the lines of refugees crossing the Pyrenees to images of half-naked anorexic bimbos in a truly surrealistic manner.

54. Manuel Rivas, El Lápiz del Carpintero (Madrid, 2000), and Javier Cercas, Soldados de Salamina (Barcelona, 200I). Rivas's work went through eight editions, 2000-2002. Cercas's novel has some direct relevance to this paper: it concerns the survival of a Francoist held by 
initiatives in Spain to uncover the mass graves of the victims of Francoist repression.5 Thirty years after Franco's death, Spaniards are finally starting to talk openly about these difficult years, and the unpretentious, libertarian texts of this last wave of refugee literature are an integral part of this process. It appears as if, finally, their message of cultural pluralism and idealism is beginning to find an audience.

Surveying these waves of writing, it is clear that one cannot identify them as single literary genre. Even John Beverly's perceptive concept of testimonio, based on "an affirmation of the individual self in a collective mode", is not sufficiently broad to encompass this spectrum of writing. ${ }^{6}$ Indeed, the entirety of the refugees' oeuvre seems to form a type of conceptual labyrinth, of "extreme plasticity", without a clear centre. ${ }^{57}$ One can identify the following important lines of division:

(I) Stylistic: Refugee writing ranges from the sophisticated modernist narrative of Le Grand Voyage to Constante's militant autobiography, which begins with the phrase "I am not a writer". ${ }^{8}$ It includes works edited by amateur and professional historians, autobiographical novels and novelistic autobiographies, political polemics and diplomatic memoirs.

(2) Political: Many writers are inspired by political ideals. One can easily identify distinct anarchist, communist, republican and socialist discourses; Catalanists and Basque nationalists could also be considered as forming separate political categories although, in practice, their works are not politicized in a comparable manner to that adopted by the leftist writers. 99

(3) Geo-cultural: Furthermore, we need to also consider a geo-cultural fragmentation: the potentially distinct Catalan and Basque memories of the war, and the development of separate, national, refugee discourses in Mexico, Russia, Britain, and France, often written in the local vernacular languages.

republican authorities near the French border in January 1939. There are plans to make a film of this work.

55. On these municipal initiatives, and the new debates concerning the conflict and its effects, see "Trois sous aux victimes de Franco", Libération, Io September 2001; "Hijos de las cárceles franquistas", El País, 24 March 2002; "Bringing Franco's Crimes to Light", The Guardian, I7 July 2002; “L'Espagne et Franco”, Libération, 25 February 2003; “Spain's Civil War Comes Back to Life", The Guardian, 8 March 2003; "Helpers Enlisted to Find Franco Victims", The Guardian, Io March 2003.

56. John Beverly, "The Margin at the Centre", in Smith and Watson, Decolonizing the Subject, pp. 9I-II4.

57. See the useful essay by P. Laborie and J.-P. Amalric, "Mémoires en devenir: la construction des sens d'exil", in Domergue, L'exil républicain à Toulouse, pp. I I-I 8, I I.

58. Mariano Constante, Les années rouges: de Guernica à Mauthausen (Vienne, 1971), p. 7.

59. On Catalan exile culture, see L. Domergue, "Les catalans en exil à Toulouse entre 19391975”, in idem, L'exil républicain à Toulouse, pp. I43-172. 
(4) Internal and external: While before 1975, all refugee writing was published outside Spain, some of these memoirs centred on the experience of the activities of the various internal oppositions after 1939. Such writers usually left Spain after 1945: they did not participate in the Retirada.

Given the "irredeemably shattered" nature of this literature, "scattered into a thousand currents", it should now be clear why there is not, and cannot be, a recognized canon of classic refugee texts and, therefore, why it is difficult, even dangerous, to make generalizations about this body of work. ${ }^{60}$ To write this paper, I have consulted approximately sixty texts by republican refugees. These vary enormously, from María Seco Mateo's 200-word interview in El Pais, through the edited collections of interviews by researchers such as Eduardo Pons Prades, to substantial works by single authors. I have used two criteria in selecting these texts: firstly, I have sought works which give some special attention to the Retirada. But, secondly, I have also consulted what might, tentatively, be termed the emblematic texts of exile figures, in order to have some scale of comparison by which to judge the first set of works. To my knowledge, there is no previously published study which focuses specifically on the Retirada.

Is there no quality which unites these refugees' works? Do they share nothing more than the most basic quality of being written by Spaniards in exile? For the period of Franco's reign, the most prudent answers to these questions might well be negative: the exile diaspora was simply too scattered, too fragmented to permit any real sense of literary or politicalcultural unity. However, one can make three significant qualifications to this negative response.

Alongside their intense and often fractious political disunity, there was a common sense of republican idealism which often inspired the refugees. This was not a narrow loyalty to one of the explicitly republican parties, which were usually small, centrist, and without a mass audience. Nor was it even a loyalty to the republic of I4 April I93 I: after 1939, many anarchists and communists were extremely critical of this regime. Instead, this common republicanism was a broad, intangible sense of idealism, centred on what might be termed "a republic of the Mind". Its icons were the revered figures of republican culture: Machado, the martyred poet, García Lorca, the executed dramatist, and Francisco Ferrer, the libertarian educationalist, shot by firing squad in 1909. ${ }^{61}$ This sense of idealism did not create any practical political programme, although it certainly included some standard features of the Enlightenment heritage (faith in progress

60. Laborie et Amalric, "Mémoires en devenir", p. I7; Puccini, "Introduction", p. 44 refers specifically to refugee poetry as "disperée en mille courants".

6I. Dreyfus-Armand, L'exil des républicains espagnols en France notes this ability of cultural causes to unite the exiles. See p. Ioo. 
and education, rationalism, anti-clericalism). More specifically, it was marked by an intense desire for a closeness between government and people, and a sense of ethical community. ${ }^{62}$

Secondly, if one turns to look more specifically at the refugees of the Retirada, and concentrates on the literature of the post-1975 period, then, arguably, there is a shared political dimension to many of these works. Goytisolo's recent analyses of the Arab contribution to Hispanic culture illuminate this tendency. ${ }^{63}$ The post-1975 authors are arguing against two monoliths: certainly, against the national-Catholic culture popularized by the Franco regime, but also against the idea of a single, consensual, nonFrancoist or post-Francoist Spanish culture. Indeed, it could also be claimed that some of the older texts of the Retirada are now acquiring a new significance: as they are clearly no longer valid as claims by would-be politicians to enter or form governments, they can now be re-read as debates concerning Spanish identity.

Our third qualification relates, once more, specifically to the Retirada, and to the refugee experience in 1939-1940. As we will see, this was a moment when the diverse strands of Spanish republican political culture were forced together by the French authorities. They shared key moments: the fear of the advancing nationalists, the journey to the border, the humiliation of their reception. While none of them can ever have felt grateful to the French government, this foreign state did push them to think of themselves as a single mass. It is this specific, shared historical experience which forms the epistemological basis for this study.

\section{BOURG-MADAME}

\section{Spain/France}

Let us begin our return to Bourg-Madame. The themes evoked by the Canción de Bourg-Madame were not new to Spanish history. As Legarreta points out that, for part of their journey, the Basque refugees of 1937 followed the medieval pilgrimage routes to Santiago de Compostella. ${ }^{64}$ The long saga of Al-Andalus (Islamic Spain), Reconquista, and Catholic Spain was also a cycle of exile and counter-exile: indeed, it can be argued that the modern, European, Spanish identity was born in exile. ${ }^{65}$ The

62. On this vague but intense political culture, see the useful collection of essays edited by Nigel Townson, El Republicanismo en España (Madrid, 1994).

63. On Goytisolo's recent political interventions see, for example, "Goytisolo defiende la resistencia y la autocrítica", El País, 29 May 2002.

64. Dorothy Legarreta, The Guernica Generation: Basque Refugee Children of the Spanish Civil War (Reno, NE, 1984), p. Is.

65. On this theme, see Alfonso Botti, Cielo y dinero: el nacionalcatolicismo en España (I88I1975) (Madrid, I993), and Francisco Márquez Villanueva, Santiago: tragectoria de un mito (Barcelona, 2004). 
nineteenth century initiated a new sequence of possession and dispossession, during which France came to function as a type of refuge nation, almost as an alternative Spain. The invasion by Napoleonic forces, the subsequent occupation, the rebellion in $\mathrm{I} 808$, and the political disturbances of early nineteenth-century Spanish history all led to successive waves of liberal, monarchist, and republican refugees seeking refuge in France. In I 83 I there were 2,687 Spanish refugees receiving a French state subsidy: they formed 48.8 per cent of the 5,500 subsidized refugees on French territory. ${ }^{66}$ The idea that France was the country of the Rights of Man and a place of refuge was formed among Spaniards during this period. It remained a powerful myth during the twentieth century. In I92I, Dolores Torres wished to marry, despite the wishes of her fiancé's family. Where did she go? She travelled 200 kilometres north to Bourg-Madame, the first parish church across the border, where the French priest was used to marrying Spanish couples who were unable to marry in their own country. ${ }^{67}$

France also became an inspiration for diverse Spanish intellectual and political currents. "El Campesino" could remember the crowds in Madrid on I4 April I93 I, spontaneously bursting out into renditions of the La Marseillaise to greet the new Spanish Republic. ${ }^{68}$ Whether one examines, for example, innovative architectural plans for Barcelona from the i 850 s to the I920s, early twentieth-century Spanish literature, or the articles printed by the PSOE's El Socialista in the late I880s, "the model is always French". ${ }^{69}$ There were, of course, opposing voices: the most important of these was Reconquista-orientated "National Catholicism" which came to dominate Spanish political culture during the early years of the Franco period, which proposed "a non-racial theory of race", and which fought French influence. ${ }^{70}$ The majority of the refugees in the Retirada, however, had every reason to accept a positive image of France as a progressive, liberal, benevolent force: they still had "a hope" that they would find a new existence in France. ${ }^{7 \mathrm{I}}$

During the course of the nineteenth century, another form of contact

66. Noiriel, Réfugiés et Sans-Papiers, p. 38.

67. Torres, Chronique d'une femme rebelle, pp. 57-58.

68. "El Campesino", Jusqu'à mort, p. 46.

69. References from, respectively, Oriol Bohigas, "Architecture in the Emerging Metropolis", in M. McCully (ed.), Homage to Barcelona (London, 1986), pp. 100-109, 109; Azorin, Ni si, ni no (Barcelona, 1965), p. 47; Paul Heywood, Marxism and the Failure of Organized Socialism in Spain, 1879-1936 (Cambridge, 1990), pp. 3, I4.

70. Marie-Aline Barrachina, "La propagande du premier franquisme et la notion de 'race spirituelle'”, in Papy, Les Espagnols et la guerre civile, pp. 27-36, 28. See also Botti, Cielo y dinero. For a more detailed review of the politics of Spanish identity, see Martin Blinkhorn's meticulously argued essay, "Spain: The 'Spanish Problem' and the Imperial Myth", Journal of Contemporary History, is (1980), pp. 5-25.

7I. Montseny, Pasión y muerte, p. 9 
between the two countries developed. The first mass migration from Spain evolved as workers and budding entrepreneurs sought their fortunes in South America and then in Cuba. ${ }^{72}$ Following 1919, however, the number of these transatlantic journeys declined. Due to the severe losses that France experienced during World War I, foreign labour was needed to ensure the continuation of French industry and agriculture, and so France became the most common destination of Spanish migrant workers. In I93 I there were approximately 750,000 Spanish workers in France, the third biggest category of such workers after the Italians and Poles. ${ }^{73}$ They were crowded into a long line of departments bordering the Pyrenees, from Bordeaux to Marseilles. In some towns they formed semi-permanent colonies.

In Bordeaux, for example, a group of anarchist exiles regularly held public meetings in Spanish for the Spaniards who lived in the suburb of Cenon, alongside Italian, Polish, and Yugoslav families. ${ }^{74}$ Gargallo Edo would later recall working in Bordeaux as a docker, a fisherman, and a cook's assistant between I 930 and I936. He was always looking for "any job, but fast", running one step ahead of the labour inspector. If discovered by the authorities, he would promptly be fired, as - like so many - his work permit was not in order. ${ }^{75}$ In the early I930s, the numbers of Spanish workers began to fall as the French economy shrank. Spanish migrants bitterly resented the French state's new policy of "national preference", whereby French workers were given priority over Spaniards. ${ }^{76}$

The revolt of July I936 led to a new cycle in Pyrenean crossings. It is often forgotten that among the first refugees were supporters of the military revolt, terrified by the unexpected determination of the republicans to defend the regime. At least one small group of Catholics and monarchists congregated in Perpignan in the summer of 1936.77 Some even followed older routes, crossing the Atlantic to Mexico. ${ }^{78}$ In the same period, however, republicans also fled from Spain. For example, the town of Jaca, in Huesca province, had elected a socialist mayor before I936. On i9 July 1936 he heard an angry crowd approach the front of the town hall.

72. On transatlantic migration patterns, see Jose C. Moya, Cousins and Strangers: Spanish Migrants in Buenos Aires, I850-1930 (Berkeley, CA, 1998).

73. Dreyfus-Armand, L'exil des républicains espagnols en France, p. 22.

74. Federico Gargallo Edo, La raison douloureuse (Madrid, I999), pp. 26, 70.

75. Ibid., pp. 79-8I.

76. The increasingly hostile French attitude to foreign workers is considered in Rahma Harouni, "Le débat autour du statut des étrangers dans les années I930", Mouvement social, i 88 (I999), pp. $6 \mathrm{I}-7 \mathrm{I}$.

77. Their presence is briefly described in José María Gironella, One Million Dead (New York, I963), p. 25.

78. They make a brief appearance in a fascinating fictional study of the process of migration: Luis Arturo Ramos, Within these Walls, Samuel A. Zimmerman (tr.) (Pittsburgh, PA, I997), p. 66. 
Guessing that this meant that nationalist forces were rebelling, he called to his colleague, the mayor of Canfranc, who was also in the building, and the two men ran out to the back of the town hall. They leapt into the mayor's car, and drove the fifty kilometres to the frontier as fast as they could, stopping only to pick up a fellow socialist deputy on the way.79

Intricate, varied patterns of criss-crossing Pyrenean journeys evolved throughout the conflict. Aside from the now well-known example of the International Brigades, other travellers left for Spain. ${ }^{80}$ David Berry has studied the French anarchists who crossed southwards, via BourgMadame, to fight in Spain. ${ }^{81}$ A more complex journey is described by Paul Schue, who considers the fate of those communist-recruited members of the International Brigades who found in Spain "a site of disillusionment" and who, on their return to France, were then exploited by the fascist Parti Populaire Français. At public meetings and in articles their experience was presented as the attainment of a type of fascist manhood, alive to the realities of the world..$^{82}$

Thus there were many examples of types of trans-Pyrenean travel known to the refugees who joined the Retirada: whether looking for work, seeking to avoid an angry parent's sanction, or aiming to study literature, many routes led over the border to Bourg-Madame. Their problem was to estimate if it was the right time to leave. We saw above how the Jaca mayor made a split-second decision. Few others made such an important decision so quickly. Instead, an integral part of the experience of the conflict was this slow, difficult, infinitely important process of weighing-up chances and prospects.

In December 1938 Mariano Constante, a soldier in the 43rd Division, briefly left the front to see his parents in Barcelona. They had recently travelled through France; he was surprised to realize that although they were civilians, they knew far more about the progress of the war than he did. ${ }^{8} 3$ Jorge Semprun recalls his family, temporarily based in the Netherlands in 1937 and 1938, gathering together each evening to discuss the course of the war. They would read the official circulars which his father, a diplomat, received, and compare them with the news from the Dutch and Spanish press. ${ }^{8}$ Semprun recalls that the news was always bad, but one

79. Recorded in Claire Arnould, "L'accueil des réfugiés espagnols en Béarn et en Soule de 1936 à 1940", in Papy, Les Espagnols et la guerre civile, pp. 337-350, 338.

80. On the International Brigades, see the well-researched paper by Rémi Skoutelsky, "L'engagement des volontaires français en Espagne républicaine", Mouvement social, i 8 I (1998), pp. 7-30.

81. David Berry, "French Anarchists in Spain", French History, 3 (1989), pp. 427-465.

82. Paul Schue, "The Prodigal Sons of Communism: Parti Populaire Français Narratives of Communist Recruitment for the Spanish Civil War and the Everyday Functioning of Party Ideology", French Historical Studies, 24 (200I), pp. 87-I I I.

83. Constante, Les années rouges, p. I25

84. Jorge Semprun, Adieu, vive clarté... (Paris, I998), p. 30. 
wonders if this was so obvious to all Spaniards. The neat lines on maps demonstrating the nationalists' military advances do not convey how republican families might have understood the course of the war. For example, Arturo Barea crossed the Pyrenean border at Le Perthus in January I 938 . His priority was to get better: he was confident that once he had recovered from his nervous breakdown, he would be able to return to Madrid for the victory parade. ${ }^{85}$ Torres was more realistic when she left her Catalan village in January 1939.

How many years would we be gone? One, two, perhaps three, perhaps even longer, five or six years: my heart started thumping, no, that could not be possible. I was always too pessimistic. To pick up my spirits, I chose the middle date: three years before coming back and finding everything as we left it. ${ }^{86}$

Alongside the Jaca mayor, Constante's, Torres's and Semprun's families, and Barea's (new) wife, we should imagine families and other small groups across republican Spain, painstakingly evaluating propaganda, rumours and experiences, trying to work out the real course of the conflict, and to estimate the possibilities available to them.

It was clear to all in December 1938, however, that the nationalists had recovered from the brief, perhaps illusory, republican victory on the Ebro river in 1938 , and that the nationalist army would soon begin its advance on Catalonia itself. The region was in a poor condition. Its population was suffering from continual food shortages, and demoralized by repeated air raids which demonstrated the nationalists' military superiority; its soldiers sensed that the republican authorities were giving priority to the defence of Madrid; and its political activists, whether libertarian or Catalanist, were resentful and suspicious of central rule. Many hoped Franco's advances would be repulsed by a heroic defence, in the same manner that the people of Madrid had fought against Franco in January 1937. Some fiery radio broadcasts by republican authorities added to this impression.

There was some fighting on the outskirts of the city on 25 and 26 January, but what impressed most observers were the long periods of deathly quiet during these days. ${ }^{87}$ "Why wasn't Barcelona defended?", asked Dolores Ibarruri, accusingly. ${ }^{88}$ In truth, however, this exhausted, poorly-fed and under-equipped region could not withstand the nationalists' rapid advance. Worse still, this was a knowledgeable population. The refugees who had flocked to Barcelona carried with them detailed information about the nature of the nationalist repression. "We knew

85. Arturo Barea, The Clash, Ilsa Barea (tr.) (London, I946), p. 3 го.

86. Torres, Chronique d'une femme rebelle, p. is 6.

87. See, for example, Muriel McDiarmid, cited in Jim Fyrth and Sally Alexander (eds), Women's Voices from the Spanish Civil War (London, I991), p. 235.

88. Dolores Ibarruri, They Shall Not Pass (New York, 1976), p. 322. See also Palencia, Smouldering Freedom, p. 35 . 
what would happen to us if we stayed." 89 Had Franco himself not boasted of his blacklist of one million republican suspects?90 There was, therefore, no real prospect of a heroic defence. Instead, the main question by the second week of January I 939 was whether Catalonia's collapse would take the form of a panic-stricken rout or an orderly retreat.

Noiriel proposes three models for migration to France. ${ }^{9 \mathrm{I}}$ In the first, a settled community decides to send one of its members temporarily to France. They recommend established travel routes and a host community. The second model centres on a particular individual, usually young, undertaking a long-term migration to escape his or her home. Definitive integration of a whole group into French society is the aim of the third model. One can immediately see that the Retirada blurs all three of these categories. Communities were involved in planning the journey; individuals certainly considered that they were escaping from Francoist Spain; and while these refugees were often organized in groups, they did not initially have any expectation of staying permanently in France. This point suggests that we are probably examining a unique event, without parallel in European history.

Was this an anarchic rout? At first sight, the enormous traffic jam, stretching northwards from Barcelona, through Figueras, to the various Pyrenean settlements must have appeared this way. Dolores Ibarruri described it as a situation of "appalling confusion", Hugh Thomas writes of "a movement of panic" and "chaos" on the road.92 "It was a disaster", commented David Granda, "a great flood of people, women, children, soldiers, driven on by the fear of the fascists just behind". 93 "Thousands of soldiers were jumbled with thousands of refugees in an incredible disorder", recalled a military transport officer. ${ }^{94}$ Moreover, the visual evidence of exhausted, emaciated people limping along mountain tracks, and crowding into the narrow streets of the small Pyrenean settlements certainly gives the impression of a complete collapse of social order.

Such impressions are misleading. The refugee texts are virtually unanimous on this point: they stress again and again their intense efforts to organize a process which may well have been, ultimately, beyond organization.

Firstly, we must note, once more, that the decision to leave came after a process of discussion and deliberation. Delso briefly records: as the "fascists" arrived at the outskirts of Barcelona, "I made up my mind to

89. Pépita Carpeña, Mémoires (Paris [etc.], 2000), p. 35.

90. Hugh Thomas, The Spanish Civil War, 3rd edn (Harmondsworth, 1986), p. 867.

91. Gérard Noiriel, Le Creuset français: histoire de l'immigration XIXe-XXe siècle (Paris, I988), pp. I $48-$ I 50.

92. Ibarruri, They Shall Not Pass, p. 322; Thomas, Spanish Civil War, p. 876.

93. MacMaster, Spanish Fighters, p. I 13.

94. Cited in Pons, Niños republicanos, p. 195. 
leave, as soon as possible."95 One can also observe how so many officials, activists, and militants made every effort to carry out their duties in as responsible a manner as possible even in these most difficult circumstances. The I,500 wounded inmates of the Camprodón hospital were transported, safely, to Prats de Mollo. ${ }^{96}$ Ten huge vans transported some 400 paintings by, amongst others, Velásquez, El Greco, and Goya out of Barcelona. ${ }^{97}$ Thomas cites the fate of prisoners from POUM (Partido Obrero de Unificación Marxista - a dissident communist party), transferred north from Barcelona by their republican captors and eventually escaping by tricking their guards, as an example of the city's chaos. It would seem more appropriate to note how structures of authority and direction were preserved for so long, even after the nationalists' occupation of the city. ${ }^{98}$

Pepita Carpeña's departure from Barcelona illustrates the attempts to organize the process, and the difficulties that the refugees faced. She was an activist in the libertarian Mujeres Libres, and recalls the last meeting of her group in Barcelona, at which it was agreed that a truck would pick them up on 25 January 1939. Following the meeting, all the group's resources were destroyed, in order to prevent them falling into the Francoists' hands. The following morning, she waited for the truck at the agreed meeting-place at $5 \mathrm{am}$. It became clear that it was not going to arrive. Danger was very close: in fact, the "fascists" entered the city the next day. Despairing, she returned to the Mujeres Libres office. To her surprise, there was a phone call, explaining that the truck driver had left in a panic, and driven off north. Another activist arranged for the truck to return, and the group left a few hours before the entry of the "fascists". 99

While these people were frightened, even terrified, this was not a panicstricken mob. One should perhaps recall the less hasty evacuations from Basque territory in 1937, when refugees "emigrated with their beliefs and their priests", as a corrective to easy stereotypes. ${ }^{100}$ While the Retirada of I939 was certainly less orderly, its participants showed a similar desire to act collectively. Consuelo Granda, a refugee from Asturias who had been evacuated to Catalonia, left in a group formed in her refugee centre: four married women, two young women and two children. ${ }^{\text {I0I }}$ Torres notes how

95. Delso, Trescientes Hombres, p. 52.

96. Francisco Moreno, "La represión en la posguerra", in Santos Julía, Víctimas de la guerra civil, pp. $275-406,283$.

97. Nancy Cunard, in Fyrth and Alexander, Women's Voices from the Spanish Civil War, p. 330; see also J. Alvarez del Vayo, Freedom's Battle (New York, I97I [1940]), p. 287.

98. See Thomas, Spanish Civil War, p. 876. On these prisoners' experience, see Sherry Mangan, "Spanish Militants Describe Their Camps", Revolutionary History, 4 (I99I), pp. 303-3 I 5.

99. Carpeña, Mémoires, pp. 35-36.

100. Aguirre, Escape Via Berlin, p. 102.

Iог. MacMaster, Spanish Fighters, p. I07. 
the families from Torregrossa, her home village in Lérida province, grouped together to help the wounded as they reached the border. "We got ourselves organized, we cut our sheets into strips, we were united [solidaires], one with another." Other women prepared soup. ${ }^{102}$ Whenever someone fell down, a crowd gathered round to offer help. ${ }^{103}$

Montseny makes some pertinent observations about group-formation among the Retirada. "These groups were united by many affinities: ideas, interests, characters and regional identities constituted units of people who were solidly welded together one to another, and who energetically resisted all attempts to separate them." ${ }^{104}$ In most cases this means that the refugees of the Retirada travelled in family groups, but there are also examples of political units like Mujeres Libres and of institutional teams, such as whole hospital units, working together to organize the process.

At this point, we should also note how the process was gendered. This can be illustrated very simply by considering the iconic images of the period. Those produced in the summer of 1936 normally show active males: forming militia, riding in commandeered cars, checking rifles, seizing control. Women do feature, but nearly always as exceptions: the social revolution was so radical that even women were armed and mobilized. ${ }^{\circ 5}$ This contrasts sharply with the images from the Retirada. There are some pictures of militiamen and soldiers marching to France, but many others focus on women and children. Correspondingly, while the most memorable accounts of the revolution and the republican war effort are written by men (Orwell, Borkenau, perhaps also Garcia and Constante), it is the less-celebrated female writers (Montseny, Torres, Delso) who produce the unforgettable accounts of the Retirada. There is also an important gendered difference in the form of narration: most male refugee-authors were actively involved in the republican war effort, whether as soldiers or in support roles. In their accounts, the Retirada appears as the next chapter, or section, following their accounts of the war effort. In other words, there is an element of continuity in their narrative. Some female writers, such as the militants of Mujeres Libres, could posit a similar continuity. For the majority of women writers, however, the Retirada constituted a sharp, radical break with the previous cultures and practices.

Among those outside organized groups or institutions, the business of organizing the Retirada usually fell to women. A minority were able to

I02. Torres, Chronique d'une femme rebelle, pp. I59, I69.

I03. Palencia, Smouldering Freedom, p. 36.

I04. Montseny, Pasión y muerte, p. 9.

I05. Bizarrely, the best collection of iconic images from this revolutionary phase of the conflict are those provided as an accompanying booklet to the record issued by the Dutch punk band, The Ex, entitled “The Spanish Revolution”, 1986, Z-Ron I I - EX 028/029. (This has since been re-released as a CD.) 
catch the last trains from Barcelona. For others, their journey began in borrowed trucks and even, for a lucky few, in cars. Motor vehicles of some form seem to have been the main form of transport to the relatively lowlying border settlement of Le Perthus (290 metres above sea level), which lay on the main road from Barcelona and Figueras. Those who travelled to Bourg-Madame had a different experience: as the road grew steeper, the trucks and cars ran out of petrol, and so the vast majority of the refugees walked at least the last stages of the journey. What were they to take with them? The choices they made are revealing. María Seco Mateo took her sewing basket, hoping to find work in France. ${ }^{106}$ Torres took sheets from her trousseau, linen, the key to her house and photographs: the choice of items from her trousseau suggests her desire for domestic continuity. ${ }^{107}$ When Ilsa and Arturo Barea crossed the border at Le Perthus, they had only a typewriter and a small case. ${ }^{108}$ Many of those who had to walk stuffed their suitcases into a handcart, and took turns in pushing it. ${ }^{109}$ Some farmers travelled with their sheep and goats.

The process of travelling strengthened a sense of group identity. Torres realized how clear it all was: "those who were not fleeing were for the enemy". ${ }^{10}$ With each village they passed through, this sense of difference was strengthened. The journey proved difficult: for Rosa Laviña, four days on foot from Palafrugell in Gerona to the border; for Jokin Gálvez Prieto, a lorry ride to Figueras, but then two days walk to La Junquera. ${ }^{\text {II }}$ These were cold, wet January days. To add to their difficulties, German aircraft attacked the lines of refugees, bombing and machine-gunning them. "Death surrounded us" commented Delso. "12 Which was safer: the roads, whose crowds made such easy targets for the German planes, or the winding tracks which led through fields, forests, and valleys? Sometimes refugees consulted with shepherds over the best route to take. ${ }^{\text {II } 3}$

The journey grew more painful as the lines of refugees reached the foothills of the Pyrenees. Snow was falling, and it grew thicker as they climbed. Each night, some died from cold, malnutrition, and exhaustion. Worn out, the refugees were unable to carry their possessions any further. "Abandoning all this was unthinkable; carrying it was impossible." "I4

106. María Seco Mateo, “Mi maletín, mi vida”, El País, I 2 January 2003, p. 6.

107. Torres, Chronique d'une femme rebelle, p. I63.

I08. Barea, The Clash, p. 3 Iо.

ı09. See, for example, MacMaster, Spanish Fighters, p. 107.

i Iо. Torres, Chronique d'une femme rebelle, p. I60.

i I I. Soriano, Éxodus, p. I74; Gálvez cited in Eduardo Pons Prades, Las guerras de los niños republicanos (1936-55) (Madrid, 1997), p. 165.

I I 2. Delso, Trescientos hombres, p. 53.

I 13. Nancy MacDonald, Homage to the Spanish Exiles: Voices from the Spanish Civil War (New York, I978), p. I87.

I 14. Ramon Moral i Querol, Journal d'Exil, 1938-1945, N. Besset and M. Prudon (trs) (Paris, I982), p. 26. 
Their route was littered with broken-down cars, cases, bundles, bags, clothing, furniture and corpses. For many, this moment was extremely painful: it signified to them, with horrific clarity, that their journey was not going to be like previous migrants' voyages to France. Torres gave up her trousseau and her photos. "At that moment, I thought about survival, about saving my skin, and not about remembering. Afterwards, when I'd escaped, I felt sad about not having anything from my past." IIs Seco recorded that as she watched her sewing basket fall down the hillside, tears ran down her cheeks. ${ }^{116}$

An important aspect of the Retirada was a sense of the overturning of marks of identity. The streets of Barcelona "were littered with paper, tornup party cards and union membership cards". ${ }^{117}$ Documents which had played a vital role in daily life suddenly became not just unnecessary, but positively dangerous. Constante recognized the symbolic importance of the order to destroy his brigade's documents. "Our documentation was destroyed; there was no hope for resistance." "I8 Over on the BelgianFrench border, Aguirre found that his group's official Spanish-republican passports were no longer accepted by the border guards. "We were being persecuted for having fought in the first trenches of democracy [...]. We were, in those moments, nothing but a group of exiles with no acceptable documents." II

Consuelo Granda records another example of this type of overturning. Having walked for two days, she was separated from her group as darkness was falling. She heard, rather than saw, a lorry draw up and dump a load of papers. In the absence of anywhere better to sleep, she picked up some clumps of these papers, and made herself an improvised bed. The next morning she was woken up by a friend laughing at her. "Don't you see what you're sleeping in?" She looked round, and realized that she had made her bed out of republican banknotes. Some refugees emptied their suitcases and filled them with wads of money, but Granda thought "I'm not going to take any". ${ }^{120}$

This simple process of travelling to the border, often not more than Io० kilometres, constituted "a journey of power". Political relationships and cultural links were being irreversibly transformed as the refugees made a decisive break with their communities. By acting to preserve their political ideals, they were cutting their links with their cultures and their homes. This break was to grow deeper as their journeys continued into French territory.

I I5. Torres, Chronique d'une femme rebelle, p. I65.

i 16. Seco, "Mi Maletín".

I 7. Ronald Fraser, Blood of Spain: The Experience of Civil War, 1936-39 (Harmondsworth, I98I), p. 482.

I 18. Constante, Années rouges, p. I28.

I 19. Aguirre, Escape via Berlin, p. 34.

I 20. MacMaster, Spanish Fighters, p. Io8. 


\section{The end of hope}

During this long march up the Pyrenees, the refugees had been sustained by one hope: “'France!' thought the unhappy refugees, their eyes fixed on the signposts that showed the way there". ${ }^{121}$ The French state, however, was extremely slow to react to their predicament. A growing xenophobia made the government reluctant to accept more immigrants, while French military experts had not predicted that the fall of Catalonia would be so terribly swift. ${ }^{\text {I22 }}$ The French government's decisions were stumbling and confused: a ruling was made on 26 January 1939 to close the frontier; it was then followed by decisions on 28 January to allow the entry of civilians, and on 5 February to allow the entry of disarmed soldiers. ${ }^{\mathrm{I} 23}$ The emotional epicentre of Montseny's Pasión et muerte concerns the days and nights when the crowds of tired, cold, hungry, terrified refugees, chased by advancing nationalist armies, waited at the frontier, wedged in tighter and tighter as more arrived from Catalonia: a stark emotional confrontation of refugee people and military state that would be enough to turn anyone into an anarchist.

The soldiers guarding the border posts added to the refugees' sense of despair: among their ranks were black, Senegalese colonial troops, a new sight to many. ${ }^{\mathrm{I} 4}$ Whether influenced by racism or not, many Spanish refugees considered that they were entering a world of inverted logic: "for the first time in the history of the world, the black race is imprisoning the white race". ${ }^{25}$ As they crossed into France, Spanish soldiers had to give up their weapons, but others reported that their possessions - watches, jewels, fountain pens - were also stolen by the border guards. ${ }^{126}$ David Granda was asked if he anything to declare. "Shit and lice", he replied. ${ }^{127}$ The French left-socialist activist and writer, Daniel Guérin, watched the refugees pass the border, and then continue, an endless ribbon winding down the hills, guarded by soldiers posted every five metres. ${ }^{\mathrm{I} 28}$ Others were struck by the sheer volume of people crowded into the narrow roads: "On the mountains each side they come", noted Nancy Cunard in the Manchester Guardian, "so that the whole landscape seems to be moving". ${ }^{129}$

I 2 I. Palencia, Smouldering Freedom, p. 37.

I 22. The French political environment is eloquently evoked in Vicki Caron, "The Missed Opportunity: French Refugee Policy in Wartime, 1939-40", in J. Blatt (ed.), The French Defeat of 1940 (Oxford, 1998), pp. I26-170.

I 23. These episodes are discussed fully in Dreyfus-Armand, L'exil des républicains espagnols en France, pp. $43-45$.

I24. See, for example, Torres, Chronique d'une femme rebelle, p. I66.

I 25. Dr José Pujols, quoted in Montseny, Pasión y muerte, p. 26.

I 26. Palencia, Smouldering Freedom, p. 37.

I 27. MacMaster, Spanish Fighters, p. I 2.

I28. Daniel Guérin, Front Populaire, révolution manquée (Paris, 1997), p. 369.

I29. Re-published in Fyrth and Alexander, Women's Voices from the Spanish Civil War, p. 330. 
Once in French territory, the refugees found that conditions were scarcely any better than on Spanish territory. One peculiar aspect of their narratives is that nearly all of them recall their ill health as they cross the border: whether broken limbs, nervous breakdowns, or unspecified "fevers". These reports are probably indicative of their condition of arrival in France. They were an exhausted people who had suffered more than most communities ever do. Their first nights on French territory were usually spent in open fields, in forests, and on hillsides, "the grass trodden down into a sort of grey compost". ${ }^{30}$ The French authorities were not able to provide the resources which the refugees so badly needed: they did not feed them, provide medical care, or put them under roofs. Some refugees even went back over the border in order to bring sheep from Spain. ${ }^{13 \mathrm{I}}$

Many male refugees record last acts of bravado. There remains a desire among them to assert, even today, that the republican soldiers were "defeated, but not beaten". ${ }^{132}$ David Granda, for example, remembers the Durruti division marching along a little road in France, "all in formation and singing", throwing food to the other refugees as they passed. ${ }^{\mathrm{I} 33}$ Jose de Barrio, a captain of the I 8th Division, remembers arriving in France on I I February 1939: "We left our zone in strict military order. The French were absolutely amazed, not only because we arrived far later than they had expected, but also because we marched with a precision of which they were incapable." 34 Constante records an incident where one of his fellow soldiers was pushed by a Senegalese guard. The Spaniard turned and hit him, knocking him to the ground. "Treat us like the human beings we are", he warned, "we're used to fighting, and we won't allow anyone to mistreat us". ${ }^{135}$

Such claims, while important for the constitution of a positive republican memory of the Retirada, seem implausible. Guérin's memories certainly record a constrasting impression. He saw "men who must have been soldiers: bandaged, dragging their feet, crushed, dazed". ${ }^{136}$ For many, the experience of crossing the border was more than they could take. Avelli Artís-Gener remembers his last night on the Spanish territory. In the morning he found five corpses hanging from the trees: a father, a mother, and three children. They had left all they possessed in a village in Lérida, and once they had lost hope they killed themselves. ${ }^{\mathrm{I} 7}$ David Granda saw a similar sight each morning he stayed in the border settlement

I30. Ibid., p. 33 I.

I3 I. MacMaster, Spanish Fighters, p. I09.

I32. Antonio García Barón, interviewed by Manuel Leguineche, "El destierro republicano", El

País, I 2 January 2003, pp. I4-24, I4.

I33. MacMaster, Spanish Fighters, p. I I ; see also Palencia, Smouldering Freedom, p. 48.

I34. Interviewed in Soriano, Éxodus, p. I 6.

I35. Constante, Années rouges, p. I 38.

I36. Guérin, Front Populaire, p. 369.

137. Cited in Pons, Niños Republicanos, p. 192. 
of Le Tour de Carol: old peasant men would use their flannel belts to hang themselves from the trees. ${ }^{13}$ Moral also recalled the tense, disappointed atmosphere of those first days in France. His group of soldiers were left to fend for themselves in a forest near Tech. They were strictly forbidden from cutting the trees. Luckily, they had bought sheep and goats with them, and they lived off meals of meat for two days, before seeing any bread. The political tensions within their unit came to the fore: the Spanish officers began to pick on the more nationalistic Catalans. Moral believed that some of the Catalans who disappeared at this point were killed by their own officers. ${ }^{139}$

For some of these exhausted, malnourished and unhealthy people, this final betrayal of their hopes in France by the French government was too much. Others, however, began a new life in these hostile circumstances.

\section{An absent family}

Instead of aid, the first official French intervention was to discipline the refugee crowds by separating the men from the women and children, thus breaking apart the groups which had formed during their march over the Pyrenees. "Cries of despair pierced the winter air. The women refused, with shrieks, to let their menfolk - many of them old and sick, others mere boys - be taken from them." ${ }^{4}{ }^{\circ}$ Consuelo Granda recalls her first night in France, in the open, trying to sleep while it snowed, with some empty suitcases around her as her only protection. From the darkness which surrounded her, she could hear "all the names of the saints' calendar being shouted: 'Rodolpho! Paquito! Josepha!'” as parents searched for their lost children. ${ }^{\text {I }}$ I These reactions demonstrate the refugees' deepest fear: the French authorities' actions were in danger of destroying their last structures of solidarity, those which had functioned during the Retirada.

Many, maybe the majority, were separated from their families. Their memoirs record how their absent spouses, children, and relatives maintained a virtual presence in their lives, almost like ghosts. Moral recalls lying in a hospital bed, smelling the stink from his own wounds, unable to sleep because of the pain, with thoughts of his wife, his daughter, his parents - all still in Barcelona - circling round his head. On 5 March I 939 he wrote in his diary "Today is the saddest day of my life". ${ }^{12}$ Barea introduces the same idea in a poignant manner. Stuck without money in the cheapest room that he could find in Paris, for the first time in his life he 
had to cook for himself. He bought a spirit lamp and a frying pan, and then "recalled the movement of my mother's hands" as she cooked. ${ }^{\text {I43 In this }}$ way, by recalling the details of his childhood, he was able to feed himself and begin writing the autobiography that became La Forja.

For "El Campesino", his absent wife and daughter became almost like a voice of conscience to him. "Out of love for them, I had to stay healthy, solid, unshakeable." ${ }^{44}$ The most powerful evocation of an absent family, however, is del Castillo's Tanguy. As the author notes in his preface, it was only his memories of his mother which "gave a sense" to the disorder and chaos of his refugee childhood. ${ }^{\mathrm{I} 5}$

\section{The French mirror}

Beyond these tragic experiences, something odd happened to every refugee as they stepped over the border. The best illustration of this comes from the memoirs of "El Campesino": this episode concerns his arrival at Petrograd. Although a member of the PCE since I929, on the ship from Le Havre he had begun to feel renewed doubts about the nature of Russian communism. On arrival at the port, their luggage was searched, and then they were met by an official delegation. There were "hymns, speeches [...] everything for a welcome which was as formal as it was frigid". ${ }^{4} 6$ "El Campesino" was surprised to see giant placards of Lenin's and Stalin's faces. Then, to his absolute amazement, he noticed among the placards one which represented his own face.

All refugees seem to have experienced something similar to this shock, if in a quite different form. As Consuelo Granda crossed the frontier one photographer shouted out to her "Stop there! Stand there!”. "Go to hell!" she replied. ${ }^{I 47}$ The refugees were emerging into a land with a hostile gaze. One element of this gaze unified them. French people tended to see all refugees as a single bloc: they failed to perceive the diverse ethnic and political currents within the Retirada. ${ }^{\mathrm{I}}{ }^{8}$ But, worse than this, refugees were received with disdain and hostility. The most common insult flung at them was "Spanish Red!". ${ }^{49}$ Francisco Pinos Vidal was called a "terrorist". ${ }^{150}$ Other terms were also heard: Barea was called a "dirty wog"

143. Barea, The Clash, p. 3 i9.

I44. "El Campesino", Jusqu'à la mort, p. i78.

I45. Miguel del Castillo, Tanguy, (Paris, I995), p. 22.

I46. "El Campesino", Jusqu'à la mort, p. I79.

I47. MacMaster, Spanish Fighters, p. I08.

148. This point is developed by L. Domergue and M. Laffranque, "Les espagnols exilés à Toulouse et la culture: l'exemple des libertaires”, in Doumergue, L'exil républicain à Toulouse, pp. 19I-206, I94.

I 49. Recorded by Constante, Années rouges, p. I48; Delso, Trescientos hombres, p. 60; Semprun, Grand voyage, p. 103.

I 50. MacDonald, Homage to the Spanish Exiles, p. 286. 
[sale metèque], while Moral discovered that the head nurse of his hospital considered all Spaniards to be agents of the Devil. ${ }^{\text {ISI }}$ All agree that this xenophobia was growing worse: by May I939, anyone talking a language other than French on the streets of Paris could expect to be accused of being a spy. ${ }^{152}$

Miguel del Castillo's activist, republican mother was estranged from her apolitical, cynical French husband during the course of the conflict: she left him to work in Madrid. She returned to France, a refugee, in March I939. Their first conversation after many months was typical of the refugees' experience.

"I suppose that, obviously, your money isn't worth anything any more."

"That's very likely, I expect."

"What a mess! And you a communist!"

"I've already told that I'm not a communist."

"Yet you've got mixed up with that scum." 53

The process described in these brief insults is a complex one. While the Spanish republicans tended to believe that they were defeated heroes or virtuous victims, these hostile French comments inflicted a sense of collective humiliation on them.

Elsewhere, Spaniards recall the sound of windows shutting as they walked down the street. ${ }^{154}$ The French were often guilty of "complete indifference" towards the refugees, according to Montseny; they had been "poisoned by fascism" thought Palencia. ${ }^{\text {Is }}$ Barea had a more complex explanation for the growing hostility which he encountered. The Spanish refugees were a symbol of the future which waited for the French. They "resented the writing on the wall because they still clutched at their hope of peace for themselves". ${ }^{156}$ These hostile acts illustrate the condition of French political culture in the months before World War II.

Conditions varied, however: some French people were more hospitable than others. Non-state organizations were created by left-wing parties, trade unions, and sometimes concerned Catholics to aid the refugees. ${ }^{157}$ Gálvez found train drivers who gave the refugee children chocolate and sweets. ${ }^{\text {Is } 8}$ Torres was eventually lodged in a friendly Provençal village with a socialist mayor. She was delighted to find that the villagers' Provençal dialect was similar to her native Catalan. ${ }^{159}$

I s. Barea, The Clash, p. 32 I; Moral, Journal, p. 50.

I 52. Antonio Ros, Diario de un refugiado republicano (Barcelona, 1975), p. 4 I8.

I53. Del Castillo, Tanguy, p. 40.

I54. Pons, Niños republicanas, p. 227.

I 55. Montseny, Pasión y muerte, p. i 8; Palencia, Smouldering Freedom, p. 66.

is6. Barea, The Clash, p. 3 I 8.

I 57. On the efforts of left-wing groups in a distant Breton community to assist the refugees, see Louis Guilloux, Salido (Paris, I976).

158. Cited in Pons, Niños republicanas.

I59. Torres, Chronique d'une femme rebelle, pp. I7I-I72. 


\section{Retorts, lessons, and the art of survival}

Delso's memoirs of this period include a pertinent point. Considering her entry into the Retirada, she wondered: "Was it bravery or madness? Or both at once? I do not know, but there is something of which I am certain: you can only teach yourself the art of survival, no one can it teach to you." ${ }^{60}$ Her words should be taken literally. The Retirada was a "journey of power": but it was also a learning experience.

The refugees of the Retirada frequently assert that they have learnt something from their experience: a hidden knowledge which was not available to most French people. The most obvious example of this is the common claim to a type of hands-on military experience. Ros found time to laugh at the "infantile optimism" of the French, who believed that the Germans could never pass the Maginot line. ${ }^{16 I}$ When Aguirre's small group of Basque refugees came under machinegun fire near the FrenchBelgian border, you can almost hear his world-weary sigh. "We had seen it all before. It was an old story to us now, we were not afraid as some others." He confidently made expert judgements about the fighting capacity of the British troops, estimating - correctly - that they would lose this battle. ${ }^{162}$ When Messerschmidt Iogs attacked Alençon in 1940, Gálvez recognized them straight away: he had seen them before, during the Retirada. ${ }^{163}$

More importantly, however, many draw some political consequences from their experience. This is neatly summed up by an exchange recorded by Montseny. She describes two French people looking at the line of refugees arriving in France. "But how is this possible? How can such a defeat have been inflicted? Whatever happened to the courage of the Spaniards? We can't imagine such a thing happening in France!' 'No? You can't imagine it?"' ${ }^{64}$ Palencia clearly could not resist adding an observation of the same nature. Recalling the insults which the refugees suffered, she noted, "just a few months later these [French] men were themselves to suffer a more humiliating defeat". ${ }^{165}$ Torres even wrote that she "never had any confidence in Pétain". ${ }^{166}$ Obviously, in many cases, such comments are written with hindsight: they constitute an after-the-event vindication of the Spanish experience.

Such claims must be treated with great caution. They do, however, reveal another dimension of the refugee experience. Alongside disposses-

I60. Delso, Trescientos hombres, p. 53 .

I6r. Ros, Diario, pp. 394-398.

162. Aguirre, Escape via Berlin, pp. 31, 52.

163. Cited in Pons, Niños republicanos.

164. Montseny, Pasión y muerte, p. I7.

165. Palencia, Smouldering Freedom, p. 66.

i66. Torres, Chronique d'une femme rebelle, p. I8 I. 
sion, isolation, and humiliation, there was not just a determination to survive, but a sense of a particular gift, a value which had been gained, learnt, or earned. Perhaps it was this admirable quality which sustained the diverse refugee communities of the diaspora throughout the dark years of the occupation, and into the r950s and i960s.

The first clear expression of this quality came six months after the Retirada. We shall watch Consuelo Granda as she prepares for the I4 July celebrations in 1939. She was not alone: in the filthy, improvised concentration camps in France, Algeria, and Morocco, inmates prepared to celebrate Bastille Day, many consciously calculating that this action might aid their integration into French society. ${ }^{167}$ Considering the sorry state of French political culture at this point, one wonders whether these Spanish exiles were perhaps the only groups in France who could sincerely participate in the festivals. Unlike Torres, Granda had not been sent to a friendly village: the local people looked at the refugees as if they were animals or savages. Should they participate in the celebrations at all? Eventually they decided they would, and they did their best to make dresses from sheets. As they arrived together, in a group, there was silence: "Look, there's the Spanish!".

Well, some boys came to dance with us for a joke; I think that they thought we could not dance and that they would have fun at our expense. But we could all dance well and after that the boys wanted to dance with us; the French girls were jealous and angry with the boys. ${ }^{168}$

And her dance continued, into the next decades, to the tune of the Canción de Bourg Madame, whirling away even until Franco's body, the regime's physical cornerstone, rotted in its hospital bed. ${ }^{169}$

\section{CONCLUSION}

Bettelheim stresses the psychological shock of the concentration-camp experience. Respectable middle-class men, who had never criticized the authorities, were the least well-equipped to survive. They tended to respond to their dilemma by believing it was a mistake, "they dared not oppose their oppressors even in thought". As they lost their status, their sense of identity was also eroded: they soon perished. "No consistent philosophy, either moral, political or social, protected their integrity or gave them the strength for an inner stand against Nazism." ${ }^{70}$

167. See, for example, Grynberg, Les camps de la honte, p. 56; Blanca, Itinéraires d'un républicaine espagnol, p. 49.

168. MacMaster, Spanish Fighters, p. I25.

I69. On the regime's later obsession with the dictator's health, see Manuel Vàzquez Montalbán, Barcelonas Andy Robinson (tr.) (London, 1992 [first published in Spanish in I990]), p. 175.

I70. Bettelheim, The Informed Heart, p. I 3 . 
The more sharp-witted inmates realized the true nature of their dilemma. If they defended their ethics and opinions, they might retain a sense of their identity, but they would not survive in the camps. If, on the other hand, they adapted whole-heartedly to the routines and rhythms of the camps, then they might survive physically, but they would lose all sense of themselves as individuals. This was a severe test. "Those who stood up well in the camps became better men, those who acted badly soon became bad men." ${ }^{171}$ Of course, it can be argued that the Spanish refugees' "extreme situation" was simply less "extreme" than that suffered by the Jewish prisoners. However, as we have seen, the shock of the Retirada was enough to drive some to suicide. Their physical and psychological agony was real enough, and it should not be dismissed.

From our brief, summary description of Bettelheim's work we can identify some of the key characteristics of the Spanish refugees' culture. Firstly, their intense idealism served them well. Once they had recovered from the exhaustion of the Retirada, it became clear that these were tough people: mentally, politically, ethically tough, as well as physically strong. Many of them had experienced being "up against the law". In a sense, the anarchists could be seen almost as experts in this condition, but alongside them Catalanists had experienced repression by the centralizing government of 1934-1935, and republicans had organized illegally during Primo de Rivera's dictatorship in the I920s. Secondly, they were a cooperative people. Their memoirs resonate with examples of mutual aid and collective effort. This spirit could be linked to the unique popularity of anarchist urban politics among the Catalans, although it should also be acknowledged that other political ideologies - Catalanism, republicanism, communism - were equally capable of inspiring astonishing feats of collective assertion. ${ }^{172}$ Delso wrote of the lesson that she had learnt from the Retirada: the "art of survival". Part of that lesson is revealed by the strengths of the refugees' writing: they learnt that no-one would speak for them, and therefore they would have to organize their own commemorative culture.

There is another distinctive aspect to the experience of the refugees of the Retirada. Their journey challenged the very concept of the border dividing France and Spain. On the one hand, the Pyrenees seem to stand almost as a perfect model of a border: a natural frontier, substantial and real, difficult for anyone to cross. The stark confrontation of Spanish refugees and Senegalese soldiers late in January 1939 seems to reinforce

171. Ibid., pp. 23-25.

172. On the anarchists' experience, see the observant analysis in Chris Ealham's articles:

"Anarchism and Illegality in Barcelona, I93 I-37", Contemporary European History, 4 (1995), pp. I33-I I, and "Class and the City: Spatial Memories of Pleasure and Danger in Barcelona, I 914-23”, Oral History, 29 (200I), pp. 33-47. 
such impressions. On the other hand, the refugees' continuing existence after 1939 muddied and blurred such clear distinctions. Who was the "real" Spain? Franco certainly possessed the armoury of the state, but the refugees forcibly claimed to represent an ideal Spain, the Spain of the poets and the intellectuals who had no place in the general's land.

Donnan and Wilson have suggested that, in recent decades, "community difference and identity now reside less in the structures which once seemed to underpin them than in the minds of the people who express them." ${ }^{173}$ The Spanish refugees' experiences and later assertions seem to demonstrate the truth of this observation: they constitute a prototype for the intricate, multi-faceted identity cultures of the twenty-first century. As early as the summer of 1939, the line of the border itself was challenged by the journeys undertaken by passeurs, illegal migrants, and guerrillas. Franco's victory was not so clear-cut as it might seem, and the refugees' defeat less decisive than the miserable queues at Bourg-Madame suggested.

And what of Bourg-Madame itself? It is still a dull place, "visibly depressed and fading" according to the 1998 Rough Guide to the Pyrenees. ${ }^{174}$ No trace remains of the Retirada: no plaque and no monument.

APPENDIX:

THE BALLAD OF BOURG-MADAME

Thanks to Chris Ealham (Department of History, Lancaster University) and Roz Tarry (National Extension College, Cambridge) for their assistance with this translation.

Españoles, salís de vuestra patria

después de haber luchado contra la invasión

caminando por tierras extranjeras

mirando hacia la estrella de la liberación

caminando por tierras extranjeras

mirando hacia la estrella de la liberación.

Camaradas caídos en la lucha

que disteis vuestra sangre por la libertad

os juramos volver a nuestra España

para vengar la afrenta de la humanidad

os juramos volver a nuestra España

para vengar la afrenta de la humanidad.

173. Hastings Donnan and Thomas M. Wilson, Borders: Frontiers of Identity, Nation and State (Oxford, 1999), p. 24.

174. Marc Dubin, The Rough Guide to the Pyrenees (London, I998), p. 202. 
A ti Franco traidor vil asesino

de mujeres y niños del pueblo español

tú que abriste las puertas al fascismo

tendrás eternamente nuestra maldición

tú que abriste las puertas al fascismo

tendrás eternamente nuestra maldición.

Spaniards leaving your homeland after having fought against the invasion, Walking through foreign lands looking towards the star of freedom, Walking through foreign lands looking towards the star of freedom.

Comrades fallen in the struggle who gave your blood for freedom, $O$ that we could return to our Spain to avenge the affront to humanity, $\mathrm{O}$ that we could return to our Spain to avenge the affront to humanity.

And so, Franco, the traitor, the vile killer of the women and children of the Spanish nation,

You, who opened the door to fascism, you will forever have our curse,

You, who opened the door to fascism, you will forever have our curse. 